This document is the accepted manuscript version of the following article:

Maringer, J., Ascoli, D., Dorren, L., Bebi, P., \& Conedera, M. (2016). Temporal

trends in the protective capacity of burnt beech forests (Fagus sylvatica L.)

against rockfal1. European Journal of Forest Research, 135(4), 657-673.

https://doi .org/10.1007/s10342-016-0962-y

\title{
Temporal trends in the protective capacity of burnt beech forests (Fagus
}

sylvatica L.) against rockfall

3

4 Janet Maringer ${ }^{\mathrm{a}, \mathrm{e}^{*}}$, Davide Ascoli ${ }^{\mathrm{b}}$, Luuk Dorren ${ }^{\mathrm{c}}$, Peter Bebi ${ }^{\mathrm{d}}$, Marco Conedera ${ }^{\mathrm{e}}$

5 a Institute of Landscape Planning and Ecology, University of Stuttgart, Keplerstr. 11,

6 D-70174 Stuttgart, jm@ilpoe.uni-stuttgart.de; +49 71168584140 (phone); +49 711

$7 \quad 68583381($ fax $)$

8 b Department of Agriculture, Forest and Food Sciences, University of Turin, via

9 Leonardo da Vinci 44, I-10095 Grugliasco, d.ascoli@unito.it

$10{ }^{\mathrm{c}}$ Bern University of Applied Sciences, School of Agricultural, Forest and Food

11 Sciences HAFL, Länggasse 85, CH-3052 Zollikofen, luuk.dorren@bfh.ch

$12{ }^{\mathrm{d}}$ Swiss Federal Institute for Forest, Snow and Landscape Research WSL, Mountain

13 Ecosystems, Flüelastrasse 11, CH-7260 Davos Dorf, bebi@slf.ch

$14{ }^{\mathrm{e}}$ Swiss Federal Institute for Forest, Snow and Landscape Research WSL, Insubric

15 Ecosystems, via Belsoggiorno 22, CH-6500 Bellinzona, Switzerland,

16 marco.conedera@wsl.ch

$17 *$ corresponding author

\section{Acknowledgement}

19 This study was partially supported by the Swiss Federal Office for the Environment

20 (FOEN). Fieldwork assistance was carried out with the support of Franco Fibbioli,

21 Simone Giavi, Marianne Steffen, Lisa Berghäuser, and Jordi Murgadas from the

22 Swiss Federal Institute for Forest, Snow and Landscape Research and Sven Hofmann

23 from the university of Karlsruhe (Germany). 


\section{Abstract}

Beech (Fagus sylvatica L.) forests covering relief rich terrain often provide direct protection for humans and their assets against rockfall. However, the efficacy in protecting against such hazards may abruptly and substantially change after disturbances such as fires, wind-throws, avalanches and insect outbreaks. To date, little knowledge exists on the mid-term protective capacity against rockfall of fireinjured beech stands. We selected 39 beech stands in the Southern European Alps that burnt with different severities over the last 40 years. We inventoried all living and dead trees in each stand and subsequently applied the rockfall model Rockfor.net to assess the protective capacity of fire-injured forests against falling rocks with volumes of $0.05,0.2$ and $1 \mathrm{~m}^{3}$. We tested forested slopes with mean gradients of $27^{\circ}, 30^{\circ}$, and $35^{\circ}$ and lengths of 75 and $150 \mathrm{~m}$.

Burnt beech forests hit by low severity fires provide nearly similar protective capacity as unburnt forests, because only thin fire-injured trees die while intermediate-sized and tall trees mostly survive. The protective capacity of moderate to high severity sites is significantly reduced, especially between 10 and 30 years after the fire. In those cases, silvicultural or technical measures may be necessary. Beside the installation of rockfall nets or dams, small-scale felling of dying trees and the placement of stems in oblique direction to the slope can mitigate the reduction of protection provided by the forest.

Keywords: forest fires, stand structure, burn severity, Rockfor.net 
In mountain regions forests often provide a direct protection for humans and for their assets against natural hazards (Dorren et al. 2005a; Brang et al. 2006). In comparison to man-built structures the protective effect of forests is naturally re-growing and relatively cost-efficient (Olschewski et al. 2012). In case of rockfall events, standing and lying trees act as barriers against falling rocks (Motta and Haudemand 2000) and the understory vegetation increases the surface uneveness that also may contribute to the energy dissipative capacity of a forest stand (Dorren et al. 2004b; Brauner et al. 2005). Whether the protection provided by a particular forest stand is effective or not is mainly determined by: (1) terrain characteristics and the total length of the forested part of a slope between the rockfall release area and the area to be protected, (2) the size and kinetic energy of the falling rock, and (3) the basal area of the forest and dendrometrical characteristics that reduce or adsorb the impact energy of falling rocks (Dorren et al. 2015).

Since forests are dynamic ecosystems, their protective capacity changes constantly. In particular, natural disturbances such as forest fires, wind-throws, insect and pest outbreaks and snow avalanches have the potential to abruptly and substantially reduce the protective capacity of the concerned stands. Their influence on the protective capacity highly depends on (1) the intensity and scale of the disturbance, (2) the resistance and resilience of the disturbed stand, and (3) on the post-disturbance management (Bebi et al. 2015). For instance, insect outbreaks or low intensity windthrow causes dispersed tree damages that increases light- and nutrient availability to favour the pre-regeneration (Kupferschmid Albisetti 2003; Collet et al. 2008; Kramer et al. 2014). In case of an immediately and comprehensive loss of living trees after the disturbance event, remnant dead wood may significantly decrease terrain patency and 
73 may thus at least partly compensate for this loss. However, slow succession rates after

74 a disturbance event and relatively fast decay of dead wood may result in a time

75 window of temporarily reduced protection against natural hazards (Bebi et al. 2015).

76 Fire affects both the pre-fire regeneration and the dead wood structure (Wohlgemuth 77 et al. 2010), which may additionally reduce the protective capacity of burnt forests 78 with respect to wind-throw areas. Unfortunately, to date little is known about fire 79 resistance and post-fire resilience of different forest types with potentially important 80 protection functions. This is particularly true for European beech (Fagus sylvatica L.)

81 forests, an often used tree species in the protection against rockfall (Perzl 2009; 82 Schmidt 2005). In the Swiss Alps, beech forests hold a share of $16 \%$ on the overall 83 protection forests against rockfall (Brändli and Huber 2015).

84 However, recent studies demonstrated that fire-injured beeches generally collapse 85 within first 20 years post-fire due to a lack in protection from heating by its thin bark 86 and subsequent infections by wood decaying fungi (Maringer et al. subm. a). Within 87 the same period, seed germination and seedlings emergence is enhanced by 88 progressive canopy opening and by the removal of thick litter layers (Ascoli et al. 89 2015; Maringer et al. subm.). Both processes highly depend on the fire severity (i.e. 90 immediate effect of fire; cf. Morgan et al., 2014). In case of very severe fires, most 91 beeches die within the first few post-fire seasons. Due to the immediate collapse of 92 seed providing trees, seed production and seedlings emergence may be hindered. 93 Additionally, fast growing early post-fire colonizers like shrubs and ferns tend to 94 build dense layers inhibiting additionally seedlings emergence (Maringer et al. 95 subm.). Contrasting, after low severe fires only a few individuals (and usually small 96 trees) are critically injured with marginal consequences to the stand dynamic. Fires of 97 intermediate severity cause a progressive dieback of the stand according to the 

proportion of the bole injured and the proliferation of decaying fungi (Conedera et al. 2007; Conedera et al. 2010; Maringer et al. subm. a). Here the probabilities of successful seed germination and seedlings emergence are highest, especially when a mast year immediately follows the fire event (Ascoli et al. 2015). Those post-fire processes in beech forests show that there might be a lack in the forest protective capacity; particularly in moderate and high fire severity stands. It is thus crucial for foresters to know about the post disturbance processes and their influence in order to prevent the related risks.

Based on the assumption that the energy release by moving rocks is compensated by either rock-soil contact (Zinggeler et al. 1991), rock-tree contact (Berger and Dorren 2007), or both, process orientated models are able to assess the protective capacity of a concerned stand. In the present study we employed the rockfall model Rockfor.net (Berger and Dorren 2007) for quantifying the protective capacity of burnt beech forests. The model was originally developed to quickly quantify the protective capacity of different structured forest stands and has been often applied in the European Alps (Berger and Dorren 2007; Wehrli et al. 2006; Kajdiž et al. 2015). We used a dataset of 39 burnt beech stands differing in terms of years post-fire ( 2 to 40 years) and burn severity (burn severity refers to the long-term fire effects; cf. Morgan et al. 2014). In particular, we evaluated the conditions (rock size, forested slope length, slope inclination, burn severity) and post-fire phases under which deficits may be expected in the protective capacity against rockfall.

\section{Materials and methods}

\subsection{Study area}

The study was conducted in the Southern European Alps across the neighboring 
122 regions of Canton Ticino (Switzerland) and Piedmont (Italy). The area is 123 characterized by a marked elevation gradient ranging from the Lake Maggiore (197 m 124 a.s.1.) to the Adula Peak (3402 m a.s.1.) in Ticino and to Punta Nordend (4609 m a.s.1.) 125 in Piedmont, respectively. The geology is characterized by the tectonics of the Alps 126 with granit and gneiss dominating the bedrock (Pfiffner 2015). Due to the relief rich 127 terrain, rockfalls are one of the major natural hazards threatening mountain 128 settlements and roads in both regions (Regione Autonoma Valle d'Aosta - Regione 129 Piemonte 2011; Ambrosi and Thüring 2005).

130 The regional climate can be described as warm and humid showing a high annual 131 precipitation gradient ranging from $778 \mathrm{~mm}$ in Piedmont (climate station Susa: $13207^{\circ} 3^{\prime} 0^{\prime} \mathrm{E}, 45^{\circ} 08^{\prime} 0^{\prime} \mathrm{N}$ ) to $1897 \mathrm{~mm}$ in Ticino (climate station Locarno Monti: $13308^{\circ} 47^{`} 43^{`} \mathrm{E}, 46^{\circ} 10^{`} 12^{`} \mathrm{~N}$ ) (ARPA 2015; MeteoSwiss 2015). More than half of the 134 annual precipitation falls during the transition seasons (April-May and September135 November), and in winter (December-March) precipitation is particularly low (162 $136 \mathrm{~mm}$ for Piedmont, $316 \mathrm{~mm}$ for Ticino). Winters are generally mild with mean January 137 temperatures around $3.5^{\circ} \mathrm{C}$, and summers are warm with mean July temperatures 138 around $21.7^{\circ} \mathrm{C}$. In summer, periods without rain may last up to thirty consecutive days 139 (Isotta et al. 2014), whereas in winter a katabatic warm and dry wind from the 140 northern Alps (north foehn) drops the relatively humidity below $20 \%$ in average on 40 141 days $\mathrm{yr}^{-1}$ (Spinedi and Isotta 2005). These north-foehn winds dry the fine fuel of the 142 forest understory and increase the fire danger. Forest fires are mostly of human origin 143 and consist of surface fires in the understory of the deciduous forests. Those fires 144 usually start from the urban-forest interface (Conedera et al. 2015) and spread into the 145 higher elevated beech belt (900-1500m a.s.1.) mostly during prolonged dry conditions 146 (Pezzatti et al. 2009). Fire in the region of Piedmont yearly affects $1.7 \%$ of the beech 
147 protection forests (Regione Autonoma Valle d’Aosta - Regione Piemonte 2011).

\subsection{Selection of fire sites and data collection}

149 Fire perimeters with less than 40 years were selected from the forest fire databases of

150 Switzerland (Pezzatti et al. 2010) and of the State Forestry Corps of Italy (Inventorio

151 nazionale delle foreste e dei serbatoi di Carbonio (INFC 2005), Corpo Forestale dello

152 stato - ispettorato generale). They were overlaid with local vegetation (Ceschi 2006;

153 Camerano et al. 2004) and geological maps in a geographical information system

154 (ArcGIS version 10.0; (C) ESRI) to identify fires in beech stands on crystalline

155 bedrock. First field observation took place in 2011 to indicate potential study sites: (i)

156 larger than 0.25 ha, (ii) with no signs of pre-fire pasture or post-fire artificial

157 plantation, (iii) and dominated by beech $(>95 \%)$ before the fire event. From the

158 initial 94 potential sites, 36 satisfied all of the selection criteria and were retained for

159 the field survey in the years 2012 and 2013 (Appendix 1).

160 Depending on the area burnt, we placed one to three transects, spaced $50 \mathrm{~m}$ apart in

161 elevation, from the unburnt to the burnt beech forests (Figure 1). Circular plots of 200

$162 \mathrm{~m}^{2}$ were placed regularly with $30 \mathrm{~m}$ distances in between starting in $10 \mathrm{~m}$ distance to

163 the burn edge and following the contour lines. Whenever possible, a minimum of one

164 control plot was placed in the unburnt beech forests at $20 \mathrm{~m}$ distance to the burn edge.

165

166 [Fig. 1 Sampling design in a burnt and unburnt beech forests with regularly placed 167 circular $200 \mathrm{~m}^{2}$ plots placed $30 \mathrm{~m}$ apart along horizontal transects (figure left). Each 168 plot is further characterized in terms of burn severity as a function of the portion of 169 dead and living beeches (photographs)] 
171 Data collection followed guidelines of the Swiss National Forest Inventory (NFI;

172 Keller 2005) with specific focus on stand stability parameters (Herold and Ulmer

173 2001). Therefore, general plot characteristics were surveyed like slope $\left[^{\circ}\right]$, aspect,

174 elevation [m a.s.1.], mircorelief (plane, convex, depression), as well as the cover of

175 inhibitors for emerging regeneration such as common bracken (Pteridium aquilinum

176 [L.] KUHN), common broom (Cytisus scoparius [L.] LINK), purple moor grass

177 (Molinia arundinacea SCHANK), as well as the surface roughness in the form of

178 deposited rocks (see Brauner et al. 2005). The coverages of common bracken,

179 common broom and purple moor grass were summed up per plot (hereafter referred to

180 as cover of early post-fire colonizers).

181 We inventoried all trees with diameter to breast height $(\mathrm{DBH}) \geq 8 \mathrm{~cm}$ and omitted

182 smaller trees because of their negligible role in the protective effectiveness (Wehrli et

183 al. 2006). Each standing tree was identified down to the species level (Wagner et al.

184 2010) and the following characteristics were recorded: vitality, i.e., tree being alive or

185 dead (snags and dead standing tree with crown portions but without visible green

186 foliage, hereafter referred to as snags), $\mathrm{DBH}$ (at $1.30 \mathrm{~m}$ to the nearest $\mathrm{cm}$ ), tree height

187 (to the nearest meter), and the percentage of crown volume killed. The latter was

188 visually estimated by the volumetric proportion of crown killed compared to the space

189 occupied by the pre-fire crown volume (Hood et al., 2007). Data collection further

190 included lying dead trees (hereafter referred to as logs) of which the average diameter

191 and the length were recorded. For both snags and logs, the wood decay stage was

192 recorded in four classes: (1) cambium still fresh, (2) knife penetrates low, cambium

193 disappeared, (3) knife penetrates into the fiber direction, but not transversely or (4)

194 knife penetrates in both directions. Lying branches and brushwood originated from

195 falling crowns of dead trees with a decay stage below 4 were assessed after the 
196 method of Brown (1974). Pieces in the $200 \mathrm{~m}^{2}$-plots were recorded in different

197 diameter classes (1: $2.5-5 \mathrm{~cm}, 2:>5-7.5 \mathrm{~cm}, 3:>7.5-15 \mathrm{~cm}, 4:>15-30 \mathrm{~cm})$ along the

198 four cardinal directions. The obtained volume was then scaled up to standard hectare

199 values $\left(\mathrm{m}^{3} \mathrm{ha}^{-1}\right)$.

200 In regions with such a relief rich terrain fires burn very heterogeneously. Therefore 201 each plot was categorized in low, moderate and high burn severity. In accordance 202 with a parallel study by Maringer et al. (subm.), we assessed burn severity by 203 calculating the ratio of post-fire and pre-fire basal area of living trees. For fire sites 204 older than 10 years, pre-fire conditions were assessed exclusively from the control 205 plots, because of fast decaying dead wood. Whereas in burnt sites younger than 10 206 years, the number of visible dead trees in burnt plots determined the pre-fire stand 207 characteristics. Based on this assumption, we defined low burn severity in plots with 208 less than $5 \%$ crown volume loss and less than $20 \%$ basal area loss. High burn severity 209 was indicated by extensive crown loss $(>50 \%)$ and basal area killed $(>60 \%)$, and all 210 plots with intermediate losses - in terms of crown and basal area - were assigned to 211 the moderate severity class.

\subsection{Analysis methods}

\subsubsection{The Rockfor.net model}

214 We employed the Rockfor.net model developed by Berger and Dorren (2007) for 215 simulating the temporal trends in the protective capacity against rockfall in fire216 injured beech stands.

217 The underlying idea of the model is to compare the theoretical basal area required for 218 absorbing the kinetic energy of downhill moving rocks $\left(\mathrm{G}_{\text {required }}\right)$ and the available 219 basal area of a particular forest stand $\left(\mathrm{G}_{\text {available }}\right)$. Therefore, the model regards all 
standing trees distributed in a forest as virtual tree lines parallel to the contour lines.

221 All trees have the same species composition and diameters (weighting of the tree species see Dorren and Berger 2005), representing the mean values in the original

223 forest stand. The model starts by calculating the total kinetic energy developed by a 224 rock falling down the slope. Then it calculates the energy dissipative capacity of each 225 tree line. The number of trees required to dissipate all kinetic energy are subsequently 226 converted in a required basal area $\left(\mathrm{G}_{\text {required }}\right)$ using the mean DBH. In the last step the 227 Rockfor.net model quantifies the protective effect of a forest stand by comparing the 228 required theoretical $\mathrm{G}_{\text {required }}$ with the available $\mathrm{G}_{\text {available }}$ (see Berger and Dorren 2007 229 for more details).

230 In the Rockfor.net model we considered also the contribution of logs, assuming that 231 their capacity of absorbing kinetic energy is proportional to the ratio between log232 diameter and rock size. Olmedo-Manich (2015) demonstrated that deposited tree logs 233 with rock/log diameter ratios between 0.8 and 1.55 favour optimal energy loss. In this 234 study we assumed that energy dissipation efficiency is linearly related to the rock/log 235 diameter ratio. The amount of lying logs was estimated in terms of volume (in $\mathrm{m}^{3} \mathrm{ha}^{-}$ $236^{1}$ ) in the field. In our tool, this volume was converted into a total log length per 237 hectare and finally into the number of potential logs impacts per hectare. Here we 238 assumed that an efficient rock-log contact, meaning with a rock/log diameter ratio of 2391 or smaller, is required every $10 \mathrm{~m}$ on a slope length of $100 \mathrm{~m}$ to stop $100 \%$ of the 240 rocks by $\operatorname{logs}$ (see also Dorren et al 2015). The following equation was used to 241 calculate the percentage of rocks stopped by $\operatorname{logs}\left(\% \mathrm{R}_{\text {stopped }}\right)$ :

$\% R_{\text {stopped }}=E f f_{\text {contact }} \times \operatorname{Vol}_{\text {Log }} \div\left(\pi \times\left(\frac{D_{t}^{2}}{2}\right)\right) \div 100 m \div 10 \times 100 \%$ eq.

Where, 
$\mathrm{Eff}_{\text {contact }}=$ rock-log contact efficiency $=\min \left[1, \mathrm{D}_{\mathrm{t}} / \mathrm{Db}\right]$

$\mathrm{D}_{\mathrm{t}}=$ tree diameter $($ in $\mathrm{m})$

$\mathrm{D}_{\mathrm{b}}=$ rock diameter (in $\left.\mathrm{m}\right)$

Vol $_{\text {Log }}=$ volume of lying logs $\left(\right.$ in $\left.\mathrm{m}^{3} \mathrm{ha}^{-1}\right)$

251 The contribution of lying branches and brushwood to rockfall energy dissipation is 252 hard to quantify in a model such as the Rockfor.net and was therefore neglected. 253 Therefore, temporal changes of their volumes were only graphically visualized (see 254 Figures 3-4).

255 In sum, the Rockfor.net model requires as input parameters both site and forest stand 256 characteristics. Required site characteristics are cliff height $(\mathrm{m})$, length of both the 257 forested and unforested slope on the trajectory of a fallen rock, and mean slope 258 inclination $\left({ }^{\circ}\right)$. Species composition, DBHs and densities of standing trees (including 259 snags) as well as diameter and length of the logs (wood decomposition rate below 4) 260 are required as stand characteristics.

\subsubsection{Input data preparation and scenario specification}

262 Data preparation followed the new rockfall protection guidelines of the 263 "Sustainability and success monitoring in the protection forests of Switzerland 264 (NaiS)" (see Frehner et al. 2005 and Dorren et al. 2015). Tree diameters were grouped 265 in four DBH-classes $(8-12 \mathrm{~cm}, 12-24 \mathrm{~cm}, 24-36 \mathrm{~cm}$, and $\geq 36 \mathrm{~cm})$ separately for 266 living and dead standing trees and standardized to number of stems per hectare. Trees 267 with large DBH values diameter most effectively dissipate the kinetic energy of 268 falling rocks, especially those of large rocks, whereas small trees significantly 269 increase the probability of rock-tree contacts due to the (generally) large stem 270 densities. Therefore, the required basal area $\left(\mathrm{G}_{\text {required }}\right)$ to stop a falling rock within a 271 specific forested slope is weighted for the $\mathrm{DBH}$-classes according to the rock size 
272 (Dorren et al. 2015). Moreover, to account for the differences in capacity of different 273 tree types to dissipate the kinetic energy of falling rocks, Rockfor.net converted the 274 proportions of the presence of 5 different tree 'types' in each stand into a mean energy 275 dissipative capacity per study site. The following 5 tree 'types' were taken into 276 account: beech, Norway spruce (Picea abies [L.] Karst.), silver fir (Abies alba Mill.), 277 other broadleaves, and other conifers (cf. Dorren and Berger 2005).

278 Further we used standardized rock sizes, mean slope gradients, cliff heights and 279 lengths of forested slopes. We defined standard rock volumes $\left(0.05 \mathrm{~m}^{3}, 0.2 \mathrm{~m}^{3}\right.$, and 1 $280 \mathrm{~m}^{3}$, which corresponds to the rock diameters $0.37 \mathrm{~m}, 0.58 \mathrm{~m}$ and $1 \mathrm{~m}$; Table 1) as 281 traditionally used in NaiS (Frehner et al. 2005, Dorren et al. 2015). In order to 282 simulate realistic field conditions, two options of horizontal distances (75 m, $150 \mathrm{~m})$ 283 have been defined in which a rock had to be stopped from the bottom of a cliff to the 284 downslope forest edge. Finally, three different slope gradients were considered 285 representing the $1^{\text {st }}\left(27^{\circ}\right)$ and $3^{\text {rd }}$ quantile $\left(35^{\circ}\right)$, as well as at the mean $\left(30^{\circ}\right)$ of the 286 slope distribution from the surveyed plots (Table 1). Slope inclination was 287 standardized after testing the statistical non-significance between tree stem densities 288 and slopes using a mixed effect model (Appendix 2).

289 The estimation of the protective effect as calculated by the Rockfor.net model 290 represents the probability of a rock to be stopped in the stand, which is expressed in 291 the following categories: $\geq 90 \%$ very good protection, $75-90 \%$ good protection, $50-$ $29275 \%$ adequate protection, $25-50 \%$ moderate protection, and $<25 \%$ inadequate 293 protection. Whether or not the level of protection provided by a forest stand is 294 sufficient, can only be determined by means of a risk analysis in which the effective 295 risk reduction of the forest is quantified and is therefore out of the scope of the 296 present paper. 
298 Table 1: Scenario specification for the Rockfor.net model Input parameters

Scenario specification
Cliff height (m)

$\operatorname{NFS}^{1}(m)$

Rock density $\left(\mathrm{kg} \mathrm{m}^{-3}\right)$

Forested slope length (m)

Mean slope inclination $\left({ }^{\circ}\right)$

Mean rock volume $\left(\mathrm{m}^{3}\right)$
$27 \quad 30$

$\begin{array}{lll}0.05 & 0.05 & 0.05\end{array}$

$0.2 \quad 0.2 \quad 0.2$
20

0

2800

${ }^{1}$ NFS: Non forested slope length between the foot of the cliff and the upper forest limit

\subsubsection{Analysis of the modeled results}

301 The protective capacity for each scenario was given as the sum of rocks stopped by 302 standing trees (living and dead) and for logs at the plot-level. The result was set to

$303100 \%$ in case the sum exceeded the $100 \%$ mark. In order to assess the temporal post-

304 fire evolution of the protective capacity, the results were plotted against the time since

305 burning and visualized using standard loess-smoothing curves (Chambers and Hastie 306 1992) separately for low, moderate and high severity sites. The corresponding unburnt 307 forests served as reference. Significant temporal trends in those smoothing curves 308 were detected by employing linear regression models with protective capacity as 309 response variable and the number of post-fire years as explanatory variable. Since the 310 protective capacity is expressed as percentage (probability), the data was log311 transformed $\left(y^{`}=\log \left(\frac{y}{1-y}\right)\right)$ and the numbers of post-fire years were included as 312 linear and quadratic term. Additionally, Mann-Whitney-Wilcox tests were applied in 
313 each of the calculated scenario for detecting significant differences in distributions of

314 the forest protective capacity in different burn severity sites and the corresponding 315 unburnt forests.

316 All analyses of the modeled results and the regression models were performed using

$317 \mathrm{R}$, the free software environment for statistical computing ( $\mathrm{R}$ Development Core 318 Team 2014). Negative binomial logistic regression models were fitted and validated 319 using the glmmADMB package (Bolker et al.). Graphical outputs are mainly based on 320 packages lattice (Deepayan 2008) and ggplot2 (Wickham and Chang 2015).

\section{Results}

\subsection{Forest characteristics and development after fire}

323 We assessed a total number of 189 plots in burnt and 27 plots in unburnt (control 324 plots) beech dominated forests. Most of the burnt plots were classified as moderate 325 (44.2\%) and high (40.3\%) (burn) severity sites, whereas only the remaining $15.5 \%$ 326 were considered as low burn severity sites. Elevation of the fire sites and the 327 corresponding unburnt forests ranged from 700 to $1486 \mathrm{~m}$ a.s.l. with mean slope 328 inclinations of $30 \pm 0.34^{\circ}$.

329 Beech grew frequently in the burnt forests, with percentages ranging from $20.75 \%$ to

$330100 \%$ (Appendix 1). The overall average tree height was $10.3 \pm 0.11 \mathrm{~m}$, and 331 approximately $2 \mathrm{~m}$ higher when referring to living trees only. Average tree density 332 was $227.6 \pm 14.4$ stems $^{-1} a^{-1}$ with a decreasing tendency from low (360.5 stems ha $\left.{ }^{-1}\right)$ 333 to high (235.7 stems ha ${ }^{-1}$ ) burn severity sites. Temporal patterns in tree densities 334 (DBH $\geq 8 \mathrm{~cm})$ followed a parabolic course, showing denser stands in early and late 335 post-fire stages and a minimum between 10 and 20 years post-fire (Figure 2).

336 In low severity sites younger than 15 years post-fire, tree densities were only slightly 
337 lower than in the unburnt forests (Figure 2). Whereas the average basal area at the 338 minimum (around 16-20 years post-fire) was only 1.5-times less than the ones 339 recorded at the early ( $\leq 9$ years) and late $(>32$ years) post-fire stages. Only few thin $340(\mathrm{DBH}<12 \mathrm{~cm})$ trees died, and densities of intermediate-sized (DBH 12-36 cm) and 341 large $(\mathrm{DBH}>36 \mathrm{~cm})$ trees remained constant throughout the post-fire period of 40 342 years.

343 In moderate severity sites, tree densities decreased by half of the densities recorded

344 for early and late post-fire stages, whereas the basal area depression lasted for 20 345 years between 10 and 32 years post-fire (Figure 2). Intermediate-sized trees 346 dominated within the first decade post-fire while their densities rapidly decreased 347 with a minimum by about 10 to 32 years post-fire. Thin and intermediate-sized trees 348 increased in densities 32 years post-fire, and tall trees were present throughout the 349 whole observation period.

350 In comparison to low and moderate burn severity, tree densities in high severity sites 351 rapidly decreased throughout all DBH classes within the first decade post-fire and 352 dropped by a factor of 2.3 from 10 to 20 years post-fire (Figure 2). After 20 years 353 post-fire, the new regeneration characterized by thin ( $\mathrm{DBH}<24 \mathrm{~cm}$ in particular) 354 trees increased and their densities doubled with each post-fire age class, peaking after 35532 years post-fire.

357 [Fig. 2 Tree densities $(\mathrm{DBH} \geq 8 \mathrm{~cm})$ for living and dead (shaded bars) trees in 358 different DBH-classes (grey color gradient) for low, moderate and high (burn) 359 severity sites and the corresponding unburnt beech forests, grouped by years post-fire]

\subsection{Surface unevenness}

361 Most burnt plots were located on a plane (46\%) surface followed by small depressions 
$362(31 \%)$, and convex (23\%) microrelief. The average coverage of rocks in a burnt plot 363 was $2 \%$, ranging from zero to maximum $30 \%$. Early post-fire colonizers grew 364 frequently after fires of moderate and high burn severity. They reached average 365 coverages of $28 \%$ in moderate and $56 \%$ in high severity sites (Figure 3 ). Over the 366 years post-fire, they increased in coverage within the first decade post-fire and peaked $367(\sim 30 \%)$ by around 20 years post-fire in moderate severity sites. In high severity sites 368 they reached a maximum coverage $(\sim 60 \%)$ after 30 years post-fire. This contrasts to 369 plots burnt of low burn severity, where early post-fire colonizers never exceeded $37025 \%$. There was no clear temporal tendency, which was similar to the pattern of early 371 post-fire colonizers in the unburnt plots. Here coverages tended to be close to zero.

373 [Fig. 3 Temporal trends for the cover of early post-fire colonizers (sum of Pteridium 374 aquilinum, Cytisus scoparius, Molinia arundinacea) visualized by loess-smoothing 375 curves (black dotted lines) including confidence intervals (grey) for the different burn 376 severity classes and the corresponding unburnt forests]

378 Pattern in the volume of lying dead branches and brushwood were similar in the 379 different burn severity sites with peaks at around 15 years post-fire (Figure 4). 380 Afterwards volumes steadily decreased reaching similar values recorded for the 381 unburnt forests. When considering different burn severities, the volume of lying 382 branches and brushwood scored highest average values $\left(106 \mathrm{~m}^{3}\right)$ in high severity sites; 383 here it was 1.5 -times higher than in moderate $\left(75 \mathrm{~m}^{3}\right)$ and low $\left(60 \mathrm{~m}^{3}\right)$ severity sites, 384 respectively. Contrastingly, no clear temporal trend was detected in the unburnt 385 forests where volumes of lying branches and brushwood never exceeded $25 \mathrm{~m}^{3} \mathrm{ha}^{-1}$. 
387 [Fig. 4 Temporal trends in the volumes $\left[\mathrm{m}^{3} \mathrm{ha}^{-1}\right]$ of lying dead branches and

388 brushwood visualized by loess-smoothing curves (black dotted lines) including 389 confidence intervals (grey) for the different burn severity classes and the 390 corresponding unburnt forests]

392 The Rockfor.net model results highlight the mid-term (first 40 years post-fire) 393 evolution of the protective capacity of burnt beech stands as a function of different 394 burn severities, rock sizes, forested slope lengths, and slope inclinations. The average 395 protective capacity aggregated over the years post-fire decreased with increasing rock 396 size, slope inclination, and shortness of the forested slope length (Table 2). The 397 protective capacity of low severity sites did not significantly differ from the unburnt 398 forests for most of the scenarios. However, for moderate and high burn severity sites 399 the protective capacity significantly differed from the unburnt forests in more than 400 half $(67 \%)$ of the scenarios (Table 2$).$ 
402

403

404

405

406

Table 2: Mean protection capacity [\%] for the different scenario specifications grouped by low, moderate and high burn severity and the corresponding unburnt forests. Similarities (MannWhitney-Wilcox tests) in the protection capacity between unburnt and burnt forests of different severities are shown in the superscript.

Forested slope length

$75 \mathrm{~m}$

$150 \mathrm{~m}$

Mean slope gradient

$27^{\circ} \quad 30^{\circ}$

$35^{\circ}$

$27^{\circ}$

$30^{\circ}$

$35^{\circ}$

rock size burn severity

\begin{tabular}{lll}
\hline $0.05 \mathrm{~m}^{3}$ & unburnt & 97 \\
& low & $96^{(\mathrm{ns})}$ \\
& moderate & $89^{(\mathrm{ns})}$ \\
& high & $73^{(*)}$
\end{tabular}

Mean protective capacity [\%]

$\begin{array}{lllll}95 & 91 & 95 & 95 & 95\end{array}$

$92^{(\mathrm{ns})}$

$87^{(\mathrm{ns})}$

$92^{\text {(ns) }}$

92(

$0.2 \mathrm{~m}^{3}$

high

$85^{(*)}$

$76^{(* *)} \quad 88^{(*)}$

$87^{(*)}$

\section{unburnt}

low

94

$68^{(* *)}$

$61^{(* *)}$

$74^{*}$

$73^{(* *)}$

$87^{(*)}$

\section{moderate}

$87^{(*)}$

84

$69 \quad 95$

$83^{(\mathrm{ns})}$

$71^{\text {(ns) }}$

$94^{\text {(ns) }}$

94

$69^{(* *)}$

\section{high}

$77^{(* *)} \quad 66^{\text {(ns) }}$

$57^{(*)}$

$89^{\text {(ns) }}$

$91^{\text {(ns) }}$

89

$1 \mathrm{~m}^{3}$

unburnt

$55^{(* * *)} \quad 49^{(* *)}$

$40^{(* * *)} \quad 73^{(*)}$

$85^{(*)}$

$84^{\text {(ns) }}$

low

$62 \quad 48$

30

$61^{\text {(ns) }}$

48

30

94

moderate

$47^{(* *)}$

$54^{(\mathrm{ns})}$

$37^{\text {(ns) }}$

$93^{\text {(ns) }}$

$67^{(* *)}$

$71^{(*)}$

high

407

Signif. codes: ‘***’ $0.001^{\text {'**’ }} 0.01^{\text {‘*’ }} 0.05$ '•’ 0.1 'ns' 1

408

409

410

Low and moderate severity sites yielded a protective capacity above 50\% (more than adequate) for small and intermediate-sized rocks regardless of the forested slope length (Figure 5-6). Only in scenarios with rocks of $0.2 \mathrm{~m}^{3}$, slope inclination $\geq 30^{\circ}$

415 and was at a minimum in scenarios combining intermediate-sized rocks with steep 416 and short forested slopes (Figure 6 a).

417 For scenarios with rocks of $1 \mathrm{~m}^{3}$ and $150 \mathrm{~m}$ forested slopes, the protective capacity of 418 the forests was above 50\% (adequate protection) for the unburnt and low severe burnt 419 forests without any clear temporal trend (Figure 7 b). In case of shorter forested 420 slopes, the protective capacity of those forest types ranged only between $25 \%$ 421 (satisfying) and 75\% (adequate) (Figure 7 a). Contrastingly, the protective capacity in moderate and high severity sites younger than 15 years post-fire rapidly decreased 
423 below $50 \%$, reaching its minimum ( $\sim 10 \%$ that is inadequate) around 20 years post424 fire.

425 The linear regression models applied to detect temporal trends in the protective 426 capacity of the burnt and unburnt forests showed significant correlations between the 427 protective effect and the linear and quadratic term of the number of post-fire years for 428 most of the moderate and high burn severity scenarios. Such a significant correlation 429 was missing for low severity sites and the unburnt forests (Appendix 3).

430 [Fig. 5 Temporal trends in the protective effect [\%] of beech stands hit by low, 431 moderate and high burn severity and the corresponding unburnt beech forests against 432 small rocks $\left[0.05 \mathrm{~m}^{3}\right], 75 \mathrm{~m}(\mathrm{a})$ and $150 \mathrm{~m}(\mathrm{~b})$ forested slopes

433 Fig. 6 Temporal trends in the protective effect [\%] of beech stands hit by low, 434 moderate and high burn severity and the corresponding unburnt beech forests against 435 intermediate-sized rocks $\left[0.2 \mathrm{~m}^{3}\right], 75 \mathrm{~m} \mathrm{(a)}$ and $150 \mathrm{~m}(\mathrm{~b})$ forested slopes

436 Fig. 7 Temporal trends in the protective effect [\%] of beech stands hit by low, 437 moderate and high burn severity and the corresponding unburnt beech forests against 438 large rocks [ $\left.1 \mathrm{~m}^{3}\right], 75 \mathrm{~m}(\mathrm{a})$ and $150 \mathrm{~m}(\mathrm{~b})$ forested slopes]

4 Discussion

441 The protective effect of forest stands against rockfall highly depends on species 442 composition, stand structure, and sustainability of the forest regeneration capacity 443 (Motta and Haudemand 2000; Dorren et al. 2004a; Dorren and Berger 2005). 444 Disturbances such as forest fires abruptly and substantially change the forest 445 structures, which may temporarily affect the protective capacity of the concerned 446 forest stand (e.g. Dorren et al. 2004a).

447 Our results show that in beech dominated stands, episodic surface fires cause little 448 changes in the tree species composition. Beech directly re-grows (Maringer et al. 449 subm.) after single fire events, resulting in stable and locally adapted forests on the 450 long-term (Dorren et al. 2004a; Rigling and Schaffer 2015).

451 However, the post-fire vertical and horizontal stand structures, as well as the amount 
452 and timing of regeneration, depends strongly on the burn severity. The forest structure 453 in low severity sites is mostly comparable to those of the unburnt forests (Keyser et 454 al. 2008). The small, fire related changes in tree density, canopy layer, and 455 regeneration dynamics do no seem to affect the overall protective effect. This 456 contrasts to moderate and high severity sites, where significant structural changes 457 occur after fire, what may cause failures in the protective effectiveness against 458 rockfall depending on the forested slope length, the mean slope gradient and the rock 459 size. Structural changes in moderate severity sites are mostly due to the dieback of 460 small and intermediate-sized trees, which goes in line with post-fire observations in 461 conifer stands (Keyser et al. 2008). Surviving tall beeches maintain to some extent the 462 protective capacity (Volkwein et al. 2011) and provide at the same time seeds for new 463 regeneration (Ascoli et al. 2015). The gradual canopy opening of the dominant tree 464 layer leads to emerging beech regeneration, so that the forest protective effect 465 increases again after 20 years post-fire. In the long-term, the mixture of surviving tall 466 and emerging small and intermediate-sized trees results in a multi-layer stand 467 structure that may better meet the protective function standards than mono-layered 468 stands (Dorren et al. 2005b; O'Hara 2006). Nevertheless, the temporary deficit in the 469 protective effectiveness of the forests seem to occur between 10 and 35 years post470 fire, especially in case of forested slopes limited in length.

471 Tree mortality in high severity sites happens immediately and concerns all tree sizes. 472 This is similar to crown fires in conifer stands (Keyser et al. 2008; Brown et al. 2013) 473 and to wind-throw areas, where most trees die immediately after the disturbance 474 event. In those areas, standing and lying dead trees mostly maintain the forest 475 protective effect (Frey and Thee 2002; Schönenberger et al. 2005; Bebi et al. 2015), 476 although their resistance decreases with time, as shown by tensile tests (Frey and 
477 Thee 2002; Bebi et al. 2012; Bebi et al. 2015). The dead wood quantity and quality 478 might be also lower in fire sites than in wind-throw areas (Wohlgemuth et al. 2010; 479 Priewasser et al. 2013), especially in case of tree species such as beech displaying a 480 rapid decaying wood (Maringer et al. subm. a). As shown by our results, the amount 481 of dead wood consistently decreases from 15 years post-fire on, contributing little in 482 the long-term to the forest protective capacity (Frey and Thee 2002). Such a loss in 483 protective capacity has to be compensated by the upcoming regeneration, which 484 might be delayed due to a lack of seed providing trees and/or a thick layer of 485 competing, fast growing early post-fire colonizers. The latter are able to prevent 486 immediate post-fire beech regeneration (Herranz et al. 1996; Ascoli et al. 2013; 487 Maringer et al. subm.), inhibiting the forest re-growth for several decades (Koop and 488 Hilgen 1987). At the same time our results indicate significantly increase in the 489 coverage of early post-fire colonizer and lying dead branches, which may contribute 490 to some extent to the protective capacity against falling rocks with volumes smaller 491 than $0.2 \mathrm{~m}^{3}$ in the first 20 years post-fire. However, to date their effective contribution 492 is hard to quantify in process-orientated models.

\section{Conclusion and practical consequences for forest managers}

494 In this paper we analyze the temporal trends in the forest protection capacity against 495 rockfall of burnt beech stands in the Southern Alps. Based on our results, standing or 496 lying dead trees should in general be left at the burnt site because they contribute 497 temporally to the forest protective effect and provide shade, moisture and nutrients to 498 the emerging tree regeneration (Maringer et al. subm.). In particular, burnt beech 499 forests hit by low severity fires provide nearly similar protective effects as unburnt 500 forests. Hence, silvicultural measures are generally not necessary, whereby the 501 protective capacity has to be assessed on an individual basis. 
502 In case of moderate to high severe fires stands may experience a temporal deficit in 503 their protective capacity between 10 to 30 years post-fire depending on the effective 504 burn severity, the rock sizes, the length of the forested slopes and the mean slope 505 gradient. The cumulative effect of dieback of pre-fire trees and slow re-growth of the 506 regeneration may drop the protective capacity below 50\%, especially in case of large 507 falling rocks on steep slopes. Consequently, silvicultural and/or technical measures 508 may be necessary in such critical scenarios depending on the risk for humans and 509 their assets in relation to the cost-benefit ratio. Beside the installation of rockfall nets 510 or walls, small-scale felling of standing dying trees and obliquely positioning of the 511 resulting logs offers a possibility to mitigate the loss in protective capacity. However, 512 directional felling has to be conducted within a particular time frame, because (i) the 513 time-lag between salvage logging and a beech mast year affects the regeneration 514 process, and (ii) beech wood decays relatively fast with progressive time (Ascoli et al. 515 2013; Maringer et al., submit. a). As mentioned by Ascoli et al. (2013; 2015), salvage 516 logging should be carried out the following winter after a beech mast year-because 517 the success of beech regeneration highly depends on quantitative seed input-, and 518 within the first five year post-fire to protect established beech saplings. Moreover, 519 weed control combined with artificial beech seed dispersal could reduce the inter520 species competition and may accelerate the establishment of a new beech generation.

521 We were not able to quantify the contribution of brushwood and coverage of early522 post-fire colonizers in the rockfall modeling. Hence further research is needed in 523 order to quantify the dissipative energy of dense shrub vegetation and their 524 implementation in process-based models. 
Appendix

Appendix 1: Investigated fire sites sorted by the date of fire. Further listed: slope $\left[{ }^{\circ}\right]$, elevation (elev. [m a.sl.]), number of plots, mean stem density [stems ha $\left.{ }^{-1}\right]$, mean basal area $\left[\mathrm{m}^{2} \mathbf{h a}^{-1}\right]$, species (F.s. $=$ Fagus sylvatica, Broad. $=$ other broadleaf species, P.a. $=$ Picea abies, Conif. $=$ other conifer species, species proportion of living trees [\%], number of plots in the corresponding

531 unburned forest (control).

\begin{tabular}{|c|c|c|c|c|c|c|c|c|c|}
\hline \multirow{2}{*}{$\begin{array}{l}\text { Location } \\
\text { Municipal }\end{array}$} & \multicolumn{4}{|c|}{ Site characteristics } & \multicolumn{3}{|c|}{ burnt forests characteristics } & \multicolumn{2}{|c|}{ control } \\
\hline & $\begin{array}{l}\text { Date of } \\
\text { fire }\end{array}$ & Slope & Elev. & $\begin{array}{l}\text { Nr. } \\
\text { plots }\end{array}$ & $\begin{array}{l}\text { Mean } \\
\text { stem } \\
\text { density }\end{array}$ & $\begin{array}{l}\text { Mean } \\
\text { basal } \\
\text { area }\end{array}$ & Species & $\begin{array}{l}\text { Species } \\
\text { proportion }\end{array}$ & $\begin{array}{l}\text { Nr. } \\
\text { plots }\end{array}$ \\
\hline Gordevio & 09.03 .73 & 24 & 1460 & 1 & 1900 & 10 & $\begin{array}{l}\text { F.s. } \\
\text { Broad. }\end{array}$ & $\begin{array}{l}97 \\
3\end{array}$ & 0 \\
\hline Moghegno & 27.11 .73 & 40 & 1100 & 3 & 883 & 38 & $\begin{array}{l}\text { F.s. } \\
\text { Broad. }\end{array}$ & $\begin{array}{l}50 \\
50\end{array}$ & 0 \\
\hline Arbedo & 20.03 .76 & 31 & 1300 & 13 & 912 & 36 & $\begin{array}{l}\text { F.s. } \\
\text { Broad. } \\
\text { P.a. }\end{array}$ & $\begin{array}{l}76 \\
22 \\
3\end{array}$ & 1 \\
\hline Sparone & 28.12 .80 & 22 & 1100 & 16 & 753 & 27 & $\begin{array}{l}\text { F.s. } \\
\text { Broad. } \\
\text { Conif. }\end{array}$ & $\begin{array}{l}62 \\
37 \\
1\end{array}$ & 1 \\
\hline Astano & 01.01 .81 & 22 & 1050 & 2 & 750 & 35 & $\begin{array}{l}\text { F.s. } \\
\text { Broad. }\end{array}$ & $\begin{array}{l}70 \\
30\end{array}$ & 0 \\
\hline Indemini & 01.01 .81 & 31 & 1200 & 12 & 613 & 13 & $\begin{array}{l}\text { F.s. } \\
\text { Broad. }\end{array}$ & $\begin{array}{l}71 \\
29\end{array}$ & 1 \\
\hline Intragna & 04.01 .87 & 27 & 1150 & 3 & 583 & 18 & F.s. & 100 & 0 \\
\hline Aurigeno & 01.08 .89 & 35 & 900 & 2 & 1500 & 25 & $\begin{array}{l}\text { F.s. } \\
\text { Broad. }\end{array}$ & $\begin{array}{l}84 \\
16\end{array}$ & 1 \\
\hline Corio & 15.02 .90 & 19 & 1080 & 10 & 295 & 26 & $\begin{array}{l}\text { F.s. } \\
\text { Broad. }\end{array}$ & $\begin{array}{l}60 \\
40\end{array}$ & 2 \\
\hline Mugena & 23.03 .90 & 19 & 900 & 6 & 108 & 29 & F.s. & 100 & 1 \\
\hline Novaggio & 10.03 .90 & 35 & 1300 & 2 & 225 & 8 & $\begin{array}{l}\text { Broad. } \\
\text { F.s. }\end{array}$ & $\begin{array}{l}38 \\
62\end{array}$ & 1 \\
\hline Rosazza & 19.01 .90 & 40 & 1000 & 5 & 460 & 49 & $\begin{array}{l}\text { F.s. } \\
\text { Broad. }\end{array}$ & $\begin{array}{l}91 \\
9\end{array}$ & 0 \\
\hline Pollegio & 09.04 .95 & 22 & 1200 & 3 & 117 & 22 & $\begin{array}{l}\text { F.s. } \\
\text { Broad. }\end{array}$ & $\begin{array}{l}56 \\
44\end{array}$ & 2 \\
\hline Tenero & 21.04 .96 & 37 & 950 & 3 & 200 & 15 & $\begin{array}{l}\text { Broad. } \\
\text { F.s. }\end{array}$ & $\begin{array}{l}18 \\
82\end{array}$ & 0 \\
\hline Arola & 04.06 .97 & 40 & 800 & 13 & 646 & 37 & $\begin{array}{l}\text { F.s. } \\
\text { Broad. }\end{array}$ & $\begin{array}{l}66 \\
34\end{array}$ & 0 \\
\hline Magadino & 15.04 .97 & 33 & 1200 & 24 & 427 & 28 & $\begin{array}{l}\text { F.s. } \\
\text { Conif. } \\
\text { Broad. }\end{array}$ & $\begin{array}{l}72 \\
2 \\
26\end{array}$ & 3 \\
\hline Ronco s. A. & 15.03 .97 & 22 & 1300 & 6 & 417 & 23 & F.s. & 100 & 1 \\
\hline Sonvico & 03.04 .97 & 24 & 1000 & 5 & 380 & 13 & $\begin{array}{l}\text { F.s. } \\
\text { Broad. }\end{array}$ & $\begin{array}{l}49 \\
51\end{array}$ & 2 \\
\hline Indimini & 19.12 .98 & 33 & 1300 & 1 & 100 & 30 & F.s. & 50 & 1 \\
\hline Gordevio & 24.04 .02 & 24 & 1400 & 5 & 490 & 31 & F.s. & 100 & 4 \\
\hline Maggia & 11.03 .98 & 14 & 1380 & 3 & 617 & 32 & F.s. & 100 & 1 \\
\hline Bodio & 17.03 .99 & 33 & 1050 & 3 & 167 & 48 & $\begin{array}{l}\text { F.s. } \\
\text { Broad. }\end{array}$ & $\begin{array}{l}62 \\
38\end{array}$ & 1 \\
\hline Dissimo & 05.04 .99 & 40 & 1000 & 3 & 900 & 27 & $\begin{array}{l}\text { F.s. } \\
\text { Broad. }\end{array}$ & $\begin{array}{l}97 \\
3\end{array}$ & 1 \\
\hline Someo & 05.08 .99 & 27 & 1450 & 3 & 433 & 35 & F.s. & 100 & 1 \\
\hline Varallo & 10.08 .99 & 29 & 1300 & 11 & 323 & 26 & $\begin{array}{l}\text { F.s. } \\
\text { Broad. }\end{array}$ & $\begin{array}{l}96 \\
4\end{array}$ & 1 \\
\hline Villadossola & 15.03 .01 & 37 & 1250 & 11 & 1009 & 27 & $\begin{array}{l}\text { F.s. } \\
\text { Broad. }\end{array}$ & $\begin{array}{l}79 \\
21\end{array}$ & 1 \\
\hline Cugnasco & 02.04 .02 & 22 & 700 & 4 & 575 & 21 & $\begin{array}{l}\text { Broad. } \\
\text { F.s. }\end{array}$ & $\begin{array}{l}53 \\
47\end{array}$ & 1 \\
\hline
\end{tabular}




\begin{tabular}{|c|c|c|c|c|c|c|c|c|c|}
\hline Ronco s.A. & 22.04 .03 & 3 & 1300 & 2 & 350 & 35 & F.s. & 100 & 1 \\
\hline \multirow[t]{2}{*}{ Condove } & 01.03 .08 & 19 & 1100 & 11 & 573 & 50 & F.s. & 98 & 1 \\
\hline & & & & & & & Broad. & 2 & \\
\hline \multirow[t]{2}{*}{ Drugno } & 26.03 .12 & 29 & 1100 & 12 & 963 & 20 & F.s. & 90 & 1 \\
\hline & & & & & & & Broad. & 10 & \\
\hline \multirow[t]{2}{*}{ Giaglione } & 03.03 .12 & 39 & 1300 & 8 & 994 & 44 & F.s. & 77 & 1 \\
\hline & & & & & & & Conif. & 21 & \\
\hline
\end{tabular}

532

533

534 535

\begin{tabular}{lll} 
Variable & Estimate & Standard error \\
\hline Intercept & 5.9 & $<0.0001$ \\
Slope & 0.009 & 0.25 \\
random intercept & Variance & StdDev. \\
& 0.33 & 0.6
\end{tabular}

536

537

538 Slopes of the plots were measured in degree and implemented as explanatory variable

539 in a mixed effect model with negative binomial distribution (Bolker et al., 2013).

540 Stem densities served as response variable, and because of the high intra-class

541 correlation fire sites were implemented as random effect in the model. The result

542 shows that slope inclination was not significant at the 0.05-level (Appendix 3), and 543 thus it was possible to use standardized slope inclination in the Rockfor.net tool. 544 Against this background, the $1^{\text {st }}\left(26.7^{\circ}\right)$ and $3^{\text {rd }}$ quantile $\left(35^{\circ}\right)$ as well as the mean $545\left(29.7^{\circ}\right)$ was used as standardized slope inclinations.

Appendix 2: Estimates and standard error of the mixed-effect model for stem densities modeled against slope inclination. 
Appendix 3: Linear regression models for temporal trends in the years post-fire (AGE) of the protective capacity of burned beech stands differing in burn severity (low, moderate, high) and the corresponding unburned forests. Models were separately conducted for scenarios differing in 550 rocks size $\left(0.05 \mathrm{~m}^{3}, 0.2 \mathrm{~m}^{3}, 1 \mathrm{~m}^{3}\right)$, forested slope length $(75 \mathrm{~m}, 150 \mathrm{~m})$ and slope inclination $\left(27^{\circ}\right.$, $551 \mathbf{3 0}^{\circ}, \mathbf{3 5}^{\circ}$ ). The sign and significance level of the predictor are displayed.

\begin{tabular}{|c|c|c|c|c|c|c|}
\hline \multicolumn{3}{|c|}{ Scenario } & \multirow[b]{2}{*}{$\begin{array}{l}\text { Burn } \\
\text { severity }\end{array}$} & \multirow[b]{2}{*}{ Intercept } & \multirow[b]{2}{*}{ AGE } & \multirow[b]{2}{*}{$\mathrm{AGE}^{2}$} \\
\hline Rock size $\left[\mathrm{m}^{3}\right]$ & $\begin{array}{l}\text { Forested } \\
\text { slope length } \\
{[\mathrm{m}]}\end{array}$ & $\begin{array}{l}\text { Slope } \\
\text { inclination } \\
{\left[{ }^{\circ}\right]}\end{array}$ & & & & \\
\hline \multirow[t]{4}{*}{0.05} & 75 & 27 & Unburned & $(+) * * *$ & ns & ns \\
\hline & & & Low & $(+) * *$ & ns & ns \\
\hline & & & Moderate & $(+) \bullet$ & ns & ns \\
\hline & & & High & $(+)^{* * *}$ & $(-)^{* *}$ & $(+) * *$ \\
\hline \multirow[t]{4}{*}{0.05} & 150 & 27 & Unburned & $(+) * * *$ & ns & ns \\
\hline & & & Low & $(+)^{* * *}$ & ns & $\mathrm{ns}$ \\
\hline & & & Moderate & $(+) * * *$ & $(-) \bullet$ & $(+) \bullet$ \\
\hline & & & High & $(+) * * *$ & $(-)^{* * *}$ & $(+) * * *$ \\
\hline \multirow[t]{4}{*}{0.05} & 75 & 30 & Unburned & $(+) * * *$ & $\mathrm{~ns}$ & ns \\
\hline & & & Low & $(+) * * *$ & $\mathrm{~ns}$ & ns \\
\hline & & & Moderate & $(+) * * *$ & $(-)^{\bullet}$ & $(+) \bullet$ \\
\hline & & & High & $(+) * * *$ & $(-)^{* * *}$ & $(+)^{* * *}$ \\
\hline \multirow[t]{4}{*}{0.05} & 150 & 30 & Unburned & $(+) * * *$ & $\mathrm{~ns}$ & ns \\
\hline & & & Low & $(+)^{* * *}$ & ns & ns \\
\hline & & & Moderate & $(+)^{* * *}$ & $(-)^{\bullet}$ & $(+) \bullet$ \\
\hline & & & High & $(+)^{* * *}$ & $(-)^{* * *}$ & $(+)^{* * *}$ \\
\hline \multirow[t]{4}{*}{0.05} & 75 & 35 & Unburned & $(+)^{* *}$ & $\mathrm{~ns}$ & ns \\
\hline & & & Low & $(+)^{* * *}$ & $\mathrm{~ns}$ & ns \\
\hline & & & Moderate & $(+) * * *$ & $(-)^{*}$ & $(+) \bullet$ \\
\hline & & & High & $(+) * * *$ & $(-)^{* * *}$ & $(+)^{* * *}$ \\
\hline \multirow[t]{4}{*}{0.05} & 150 & 35 & Unburned & $(+) * * *$ & $\mathrm{~ns}$ & $\mathrm{~ns}$ \\
\hline & & & Low & $(+) * * *$ & ns & ns \\
\hline & & & Moderate & $(+)^{* * *}$ & $(-)^{\bullet}$ & $(+) \bullet$ \\
\hline & & & High & $(+) * * *$ & $(-)^{* * *}$ & $(+)^{* * *}$ \\
\hline \multirow[t]{4}{*}{0.2} & 75 & 27 & Unburned & $(+) * * *$ & $\mathrm{~ns}$ & ns \\
\hline & & & Low & $(+)^{* * *}$ & & ns \\
\hline & & & Moderate & $(+)^{* * *}$ & $(-)^{* *}$ & $(+)^{* *}$ \\
\hline & & & High & $(+)^{* * *}$ & $(-)^{* * *}$ & $(+)^{* * *}$ \\
\hline \multirow[t]{4}{*}{0.2} & 150 & 27 & Unburned & $(+) * * *$ & ns & ns \\
\hline & & & Low & $(+) * * *$ & $\mathrm{~ns}$ & ns \\
\hline & & & Moderate & $(+) * * *$ & $(-)^{*}$ & $(+)^{*}$ \\
\hline & & & High & $(+) * * *$ & $(-)^{* * *}$ & $(+)^{* *}$ \\
\hline \multirow[t]{4}{*}{0.2} & 75 & 30 & Unburned & $(+)^{* *}$ & ns & ns \\
\hline & & & Low & $(+) * * *$ & & \\
\hline & & & Moderate & $(+)^{* * *}$ & $(-)^{* * *}$ & $(+)^{* * *}$ \\
\hline & & & High & $(+) * * *$ & $(-)^{* * *}$ & $(+)^{* * *}$ \\
\hline \multirow[t]{4}{*}{0.2} & 150 & 30 & Unburned & $(+) * * *$ & ns & ns \\
\hline & & & Low & $(+) * * *$ & ns & ns \\
\hline & & & Moderate & $(+) * * *$ & $(-)^{*}$ & $(+)^{*}$ \\
\hline & & & High & $(+) * * *$ & $(-)^{* * *}$ & $(+)^{* * *}$ \\
\hline \multirow[t]{4}{*}{0.2} & 75 & 35 & Unburned & $(+) * * *$ & $(-)^{* *}$ & $(+)^{* *}$ \\
\hline & & & Low & $(+)^{*}$ & ns & ns \\
\hline & & & Moderate & $(+) * * *$ & $(-)^{* *}$ & $(+)^{*}$ \\
\hline & & & High & $(+) * * *$ & $(-)^{* * *}$ & $(+)^{* * *}$ \\
\hline \multirow[t]{2}{*}{0.2} & 150 & 35 & Unburned & $(+)^{* *}$ & $\mathrm{~ns}$ & ns \\
\hline & & & Low & $\begin{array}{l}(+)^{* * *} \\
(+) * * *\end{array}$ & $\mathrm{nS}$ & $\begin{array}{l}\mathrm{nS} \\
(+) * *\end{array}$ \\
\hline
\end{tabular}




\begin{tabular}{|c|c|c|c|c|c|c|}
\hline & & & High & $(+) * * *$ & $(-)^{* * *}$ & $(+)^{* * *}$ \\
\hline \multirow[t]{4}{*}{1} & 75 & 27 & Unburned & ns & $\mathrm{ns}$ & ns \\
\hline & & & Low & ns & $\mathrm{ns}$ & ns \\
\hline & & & Moderate & $(+)^{* *}$ & $(-)^{*}$ & $(+) \bullet$ \\
\hline & & & High & $(+) * * *$ & $(-)^{* * *}$ & $(+) * * *$ \\
\hline \multirow[t]{4}{*}{1} & 150 & 27 & Unburned & $(+) * * *$ & ns & $(-)^{*}$ \\
\hline & & & Low & $(+)^{* * *}$ & - & ns \\
\hline & & & Moderate & $(+)^{* * *}$ & $(-)^{*}$ & $(+)^{*}$ \\
\hline & & & High & $(+) * * *$ & $(-)^{* * *}$ & $(+) * * *$ \\
\hline \multirow[t]{4}{*}{1} & 75 & 30 & Unburned & ns & ns & ns \\
\hline & & & Low & ns & ns & ns \\
\hline & & & Moderate & $(+)^{*}$ & $(-)^{* *}$ & - \\
\hline & & & High & $(+) * * *$ & $(-) * * *$ & $(+)^{* * *}$ \\
\hline \multirow[t]{4}{*}{1} & 150 & 30 & Unburned & $(+) * * *$ & $(-)^{* *}$ & $(+)^{* *}$ \\
\hline & & & Low & $(+)^{*}$ & ns & \\
\hline & & & Moderate & $(+)^{* * *}$ & $(-)^{* *}$ & $(+)^{* *}$ \\
\hline & & & High & $(+)^{* * *}$ & $(-) * * *$ & $(+) * * *$ \\
\hline \multirow[t]{4}{*}{1} & 75 & 35 & Unburned & ns & $(-) \bullet$ & ns \\
\hline & & & Low & $(+) * *$ & ns & ns \\
\hline & & & Moderate & $(+)^{*}$ & $(-)^{* *}$ & $(+) \bullet$ \\
\hline & & & High & $(+)^{* *}$ & $(-)^{* * *}$ & $(+)^{* * *}$ \\
\hline \multirow[t]{4}{*}{1} & 150 & 35 & Unburned & $\mathrm{ns}$ & ns & ns \\
\hline & & & Low & ns & ns & ns \\
\hline & & & Moderate & $(+)^{*}$ & $(-)^{* *}$ & $(+) \bullet$ \\
\hline & & & High & $(+)^{* * *}$ & $(-)^{* * *}$ & $(+)^{* * *}$ \\
\hline
\end{tabular}


555

556

557

558

559

560

561

562

563

564

565

566

567

568

569

570

571

572

573

574

575

576

577

578

579

580

581

582

583

584

585

586

587

588

589

590

591

592

593

594

595

596

597

598

599

600

601

602

Ambrosi C, Thüring M (2005) Statistical analysis of rockfall frequency - volume relationship in Ticino (Switzerland) based on historical data. Swiss Geoscience meeting, Zürich

Arpa Piemonte. http://www.arpa.piemonte.it/banca-dati-meteorologica. Accessed 01 February 2015

Ascoli D, Castagneri D, Valsecchi C, Conedera M, Bovio G (2013) Post-fire restoration of beech stands in the Southern Alps by natural regeneration. Ecol Eng 54: 210-217. doi: 10.1016/j.ecoleng.2013.01.032

Ascoli D, Vacchiano G, Maringer J, Bovio G, Conedera M (2015) The synchronicity of masting and intermediate severity fire effects favors beech recruitment. Forest Ecol Manag 353:126-135. doi: 10.1016/j.foreco.2015.05.031.

Bebi P, Teich M, Schwaab J, Krumm F, Walz A, Grêt-Regamey A (2012) Entwicklung und Leistung von Schutzwäldern unter dem Einfluss des Klimawandels. Schlussbericht im Rahmen des Forschungsprogramms "Wald und Klimawandel", Bern

Bebi P, Putallaz J, Frankhauser M, schmid U, Schwitter R, Gerber W (2015) Die Schutzfunktion in Windwurfflächen. Swiss Forestry Journal 166:168-176

Berger F, Dorren L (2007) Principles of the tool Rockfor.net for quantifying the rockfall hazard below a protection forest. Schweizer Zeitschrift für Forstwesen 158:157-165

Bolker B, Skaug H, Magnusson A, Nielsen A (2012) Getting started with the glmmADMB package. R Core Team. http://glmmadmb.r-forge.rproject.org/glmmADMB.html. Accessed 25 January 2015

Brändli U-B, Huber M (2015) Schweizerisches Landesforstinventar LFI, Ergebnisse zur Erhebung 2004-06. Spezialanfertigung vom 25.11.2015. Eidgenössische Forschungsanstalt für Wald, Schnee und Landschaft (WSL), Birmensdorf

Brang P, Schönenberger W, Frehner M, Schwitter R, Thormann J, Wasser B (2006) Management of protection forests in the European Alps: an overview. For. Snow Landsc. Res. 80: 23-44

Brauner M, Weinmeister W, Agner P, Vospernik S, Hoesle B (2005) Forest management decision support for evaluating forest protection effects against rockfall. Forest Ecol Manag 107: 75-85. doi: 10.1016/j.foreco.2004.10.018

Brown J (1974) Handbook for inventorying downed woody material. USDA Forest Service General Technical Report INT - 16 - Rocky Mountain Research Station, Utah. http://www.fs.fed.us/rm/pubs int/int_gtr016.pdf. Accessed 1 November 2015

Brown MJ, Kertis J, Huff MH (2013) Natural tree regeneration and coarse woody debris dynamics after a forest fire in the Western Cascade Range. USDA Forest Service - Research Paper PNW-RP-592. Pacific Northwest Research Station, Portland. http://www.fs.fed.us/pnw/pubs/pnw_rp592.pdf. Accessed 1 Nobember 2015

Camerano P, Gottero F, Terzuolo P, Varese P (2004) Tipi forestali del Piemonte. Blu Edizioni, Torino

Ceschi I (2006) Il bosco nel Canton Ticino. Armando Dadó Editore, Locarno

Chambers JM, Hastie TJ (1992) Statistical Models in S. Local regression models. CRC Press LLC, Boca Raton (USA)

Collet C, Piboule A, Leroy O, Frochot H (2008) Advance Fagus sylvatica and Acer pseudoplatanus seedlings dominate tree regeneration in a mixed broadleaved 
former coppice-with-standards forest. Forestry 81: 135-150. doi: 10.1093/forestry/cpn004

Conedera M, Lucini L, Holdenrieder O (2007) Pilze als Pioniere nach Feuer. Wald und Holz 11: 45-48

Conedera, M., Lucini, L., Valese, E., Ascoli, D., Pezzatti, G. (Eds.) 2010 Fire resistance and vegetative recruitment ability of different deciduous tree species after low- to moderate-intensity surface fires in southern Switzerland. In: Viegas, D.X. (ed) VI International Conference on Forest Fire Research, 15-18 November 2010, Coimbra, Portugal. [CD-ROM]. Portugal, ADAI/CEIF University of Coimbra

Conedera M, Tonini M, Oleggini L, Orozco CV, Leuenberger M, Pezzatti G (2015) Geospatial approach for defining the Wildland-Urban Interface in the Alpine environment. Computers, Environment and Urban Systems 52: 10-20

Deepayan S (2008) Lattice: multivariate data visualization with R. Springer, New York (USA)

Dorren L, Berger F, Imeson AC, Maier B, Rey F (2004a) Integrity, stability and management of protection forests in the European Alps. Forest Ecol Manag 195:165-176

Dorren L, Maier B, Putters US, Seijmonsbergen AC (2004b) Combining field and modelling techniques to assess rockfall dynamics on a protection forest hillslope in the European Alps. Geomorphology 57: 151-167. doi: 10.1016/S0169$555 \mathrm{X}(03) 00100-4$

Dorren L, Berger F (2005) Stem breakage of trees and energy dissipation during rockfall impacts. Tree Physiol 26: 63-71

Dorren L, Berger F, Hir C, Mermin E, Tardif P (2005a) Mechanisms, effects and management implications of rockfall in forests. Forest Ecol Manag 215: 183-195. doi: 10.1016/j.foreco.2005.05.012

Dorren L, Berger F, Maier B (2005b) Der Schutzwald als Steinschlagnetz. LWFaktuell 50: 25-27

Dorren L, Berger F, Frehner M, Huber M, Kühne K, Métral R, Sandri A, Schwitter R, Thormann J, Wasser B (2015) Die neue NaiS-Anforderungsprofil Steinschlag. Swiss Forestry Journal 166: 16-23

ESRI: ArcGIS Desktop: Release 10. (Environmental Systems Research Institute: Redlands, CA)

Frehner M, Wasser B, Schwitter R (2005) Nachhaltigkeit und Erfolgskontrolle im Schutzwald. Wegleitung für Pflegemassnahmen in Wäldern mit Schutzfunktion. Bundesamt Umwelt Wald Landschaft, Bern

Frey W, Thee P (2002) Avalanche protection of windthrow areas: A ten year comparison of cleared and uncleared starting zones. Forest Snow and Landscape Research 77: 89-107

Herold A, Ulmer U (2001) Stand stability in the Swiss National Forest Inventory: assessment technique, reproducibility and relevance. Forest Ecol Manag 145: 2942. doi: 10.1016/S0378-1127(00)00572-7

Herranz J, Martinez-Sanchez J, Las Heras J de, Ferrandis P (1996) Stages of plant succession in Fagus sylvatica L. and Pinus sylvestris L. in forests of Tejera Negra Natural Park (Central Spain), three years after fire. Israel Journal of Plant Science 44: 347-358

Hood SM, Smith SL, Cluck DR (2007) Delayed conifer tree mortality following fire in California. USDA Forest Service, pp. 261-283. 

http://www.fs.fed.us/psw/publications/documents/psw_gtr203/psw_gtr203 019ho od.pdf. Accessed 1 February 15

Isotta FA, Frei C, Weilguni V, Perčec Tadić M, Lassègues P, Rudolf B, Pavan V, Cacciamani C, Antolini G, Ratto S, Munari M, Micheletti S, Bonati V, Lussana C, Ronchi C, Panettieri E, Marigo G, Vertačnik G (2014) The climate of daily precipitation in the Alps: development and analysis of a high-resolution grid dataset from pan-Alpine rain-gauge data. Int J Climatol 34: 1657-1675. doi: 10.1002/joc.3794

Kajdiž P, Diaci J, Rebernik J (2015) Modelling facilitates silvicultural decisionmaking for improving the mitigating effect of beech (Fagus sylvatica L.) dominated alpine forest against rockfall. Forests 6: 2178-2198. doi: $10.3390 / \mathrm{f} 6062178$

Keller M (Eds.) (2005) Schweizerisches Landesforstinventar. Anleitung für die Feldaufnahmen der Erhebung 2004-2007. Druckzentrum Schütz AG, Birmensdorf

Keyser TL, Lentile LB, Smith FW, Shepperd WD (2008) Changes in forest structure after a large, mixed-severity wildfire in Ponderosa Pine Forests of the Black Hills, South Dakota, USA. Forest Science 54: 328-338

Koop H, Hilgen P (1987) Forest dynamics and regeneration mosaic shifts in unexploited beech (Fagus sylvatica) stands at Fontainebleau (France). Forest Ecol Manag 20: 135-150

Kramer K, Brang P, Bachofen H, Bugmann H, Wohlgemuth T (2014) Site factors are more important than salvage logging for tree regeneration after wind disturbance in Central European forests. Forest Ecol Manag 331:116-128

Kupferschmid Albisetti A (2003) Zerfall und Verjüngung eines Schutzwaldes nach dem Absterben der Fichten durch Buchdruckerbefall. GAIA 12: 271-274

Maringer J, Conedera M, Ascoli D, Schmatz DR, Wohlgemuth T (submitted) Resilience of European beech forests (Fagus sylvatia L.) after fire in a global climate change context. Int J Wildland Fire

Maringer J, Ascoli D, Küffer N, Conedera M (submitted a) What drives European beech (Fagus sylvatica L.) to death after forest fires of varying severities? Forest Ecol Manag

MeteoSwiss (2015) Swiss climate. Federal Office of Meteorology and Climatology. Zürich, Switzerland. http://www.meteoschweiz.admin.ch/home.html?tab=overview. Accessed 1 February 15

Morgan P, Keane RE, Dillon GK, Jain TB, Hudak AT, Karau EC, Sikkink PG, Holden ZA, Strand EK (2014) Challenges of assessing fire and burn severity using field measures, remote sensing and modeling. Int J Wildland Fire 23: 1045-1060. doi: 10.1071/WF13058

Motta R, Haudemand J (2000) Protective forests and silvicultural stability: an example of planning in the Aosta Valley. Mountain Research and Development 20: $180-187$

O'Hara K (2006) Multiaged forest stands for protection forests: concepts and applications. Forest Snow and Landscape Research 80: 45-55

Olmedo-Manich I (2015) Etude expérimentale et numérique de l'efficacité d'ouvrages ligneux de génie biologique pare-pierres. Dissertation, INSA Lyon

Olschewski R, Bebi P, Teich M, Wissen Hayek U, Grêt-Regamey A (2012) Avalanche protection by forests - A choice experiment in the Swiss Alps. Journal of Forest Policy and Economics 15:108-113 
Perzl F (2009) Die Buche - eine Baumart des Objektschutzwaldes. BFW Praxisinformation 12:29-31

Pezzatti G, Bajocco S, Torriani D, Conedera M (2009) Selective burning of forest vegetation in Canton Ticino (Southern Switzerland). Plant Biosystems 143: 069620. doi: 10.1080/11263500903233292

Pezzatti G, Reinhard M, Conedera M (2010) Swissfire: Die neue schweizerische Waldbranddatenbank. Swiss Forestry Journal 161: 465-469

Pfiffner AO (2015) Geologie der Alpen, 3rd edn. Haupt-Verlag, Bern

Priewasser K, Brang P, Bachofen H, Bugmann H, Wohlgemuth T (2013) Impact of salvage-logging on the status of deadwood after windthrow in Swiss forests. Eur J Forest Res 2:231-240. doi: 10.1007/s10342-012-0670-1

R Development Core Team (2014) R: A language and environment for statistical computing, Vienna, Austria

Regione Autonoma Valle d'Aosta (2010) Regione Piemonte Foreste di protezione Diretta. Disturbi naturali e stabilità nelle Alpi occidentali, Arezzo

Rigling A, Schaffer HP (2015) Waldbericht 2015. Zustand und Nutzung des Schweizer Waldes. Eign. Forschungsanstalt für Wald, Schnee und Landschaft, Birmensdorf

Schmidt O (2005) Zur Gefährdung der Hauptbaumarten aus Sicht des biotischen Waldschutzes. LWFaktuell 49:1-2

Schönenberger W, Noack A, Thee P (2005) Effect of timber removal from windthrow slopes on the risk of snow avalanches and rockfall. Forest Ecol Manag 213: 197208. doi: 10.1016/j.foreco.2005.03.062

Spinedi F, Isotta FA (2005) Il clima del Ticino negli ultimi 50 anni. Dati statistiche e società 4:4-39

Volkwein A, Schellenberg K, Labiouse V, Agliardi F, Berger F, Bourrier F, Dorren L, Gerber W, Jaboyedoff M (2011) Rockfall characterisation and structural protection - a review. Nat Hazard Earth Sys 11: 2617-2651. doi: 10.5194/nhess11-2617-2011

Wagner S, Collet C, Madsen P, Nakashizuka T, Nyland R, Sagheb-Talebi K (2010) Beech regeneration research: from ecological to silvicultural aspects. Forest Ecol Manag 259: 2172-2182. doi: 10.1016/j.foreco.2010.02.029

Wehrli A, Dorren L, Berger F, Zingg A, Schönenberger W (2006) Modelling longterm effects of forest dynamics on the protective effect against rockfall. Forest Snow and Landscape Research 80: 57-76

Wickham H, Chang W (2015) Package 'ggplot2'. https://cran.rproject.org/web/packages/ggplot2/ggplot2.pdf. Accessed 1 December 2015

Wohlgemuth T, Brigger A, Gerold P, Laranjeiro L, Moretti M, Moser B, Rebetez M, Schmatz DR, Schneiter G, Sciacca S, Sierro A, Weibel P, Zumbrunnen T, Conedera M (2010) Leben mit Waldbrand. Merkblatt für die Praxis 46: 1-16

Zinggeler A, Krummenacher B, Kienholz H (1991) Steinschlagsimulation in Gebirgswäldern. Berichte und Forschungen des Geographischen Instituts der Universität Fribourg, Universität Fribourg 


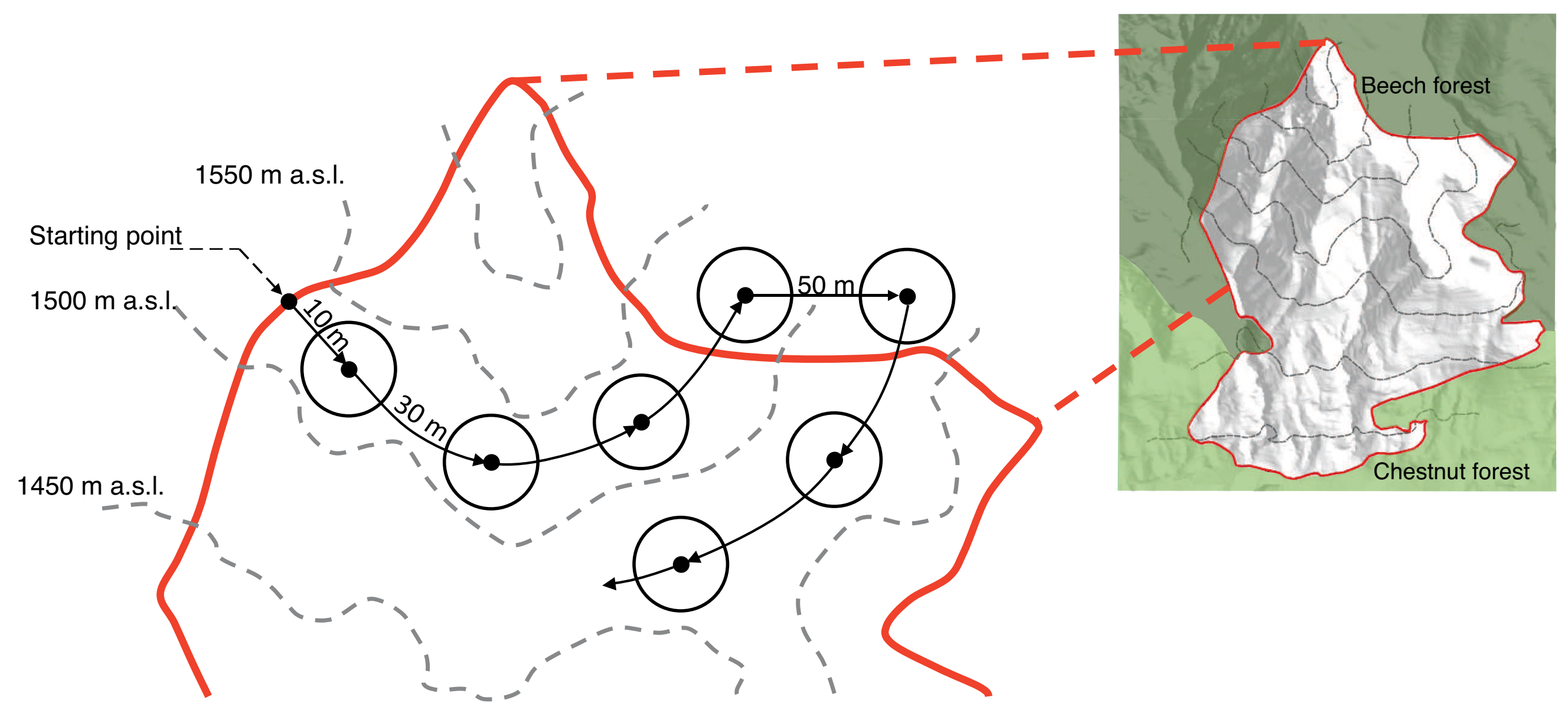

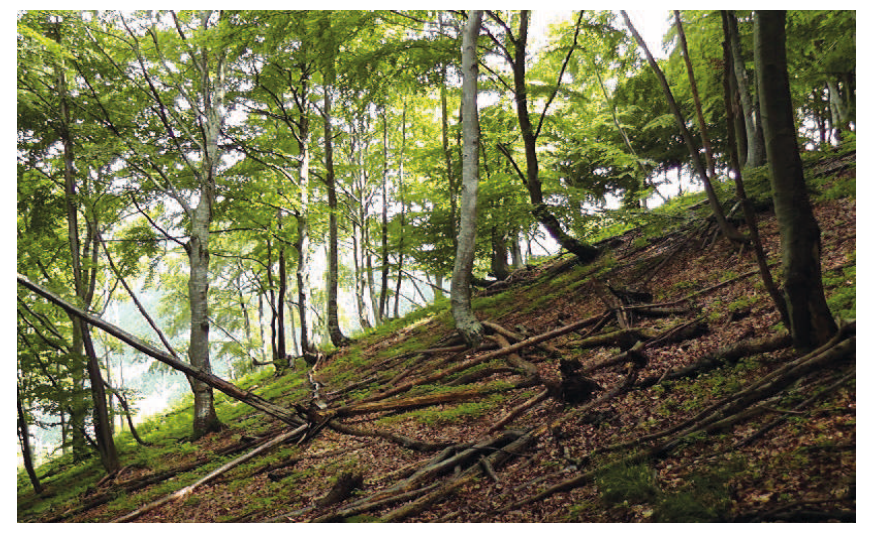

Low fire severity

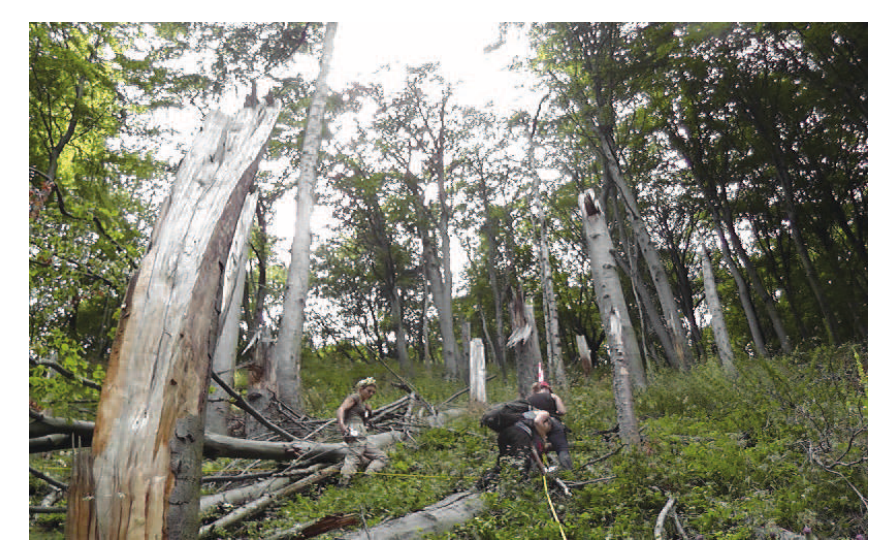

Moderate fire severity

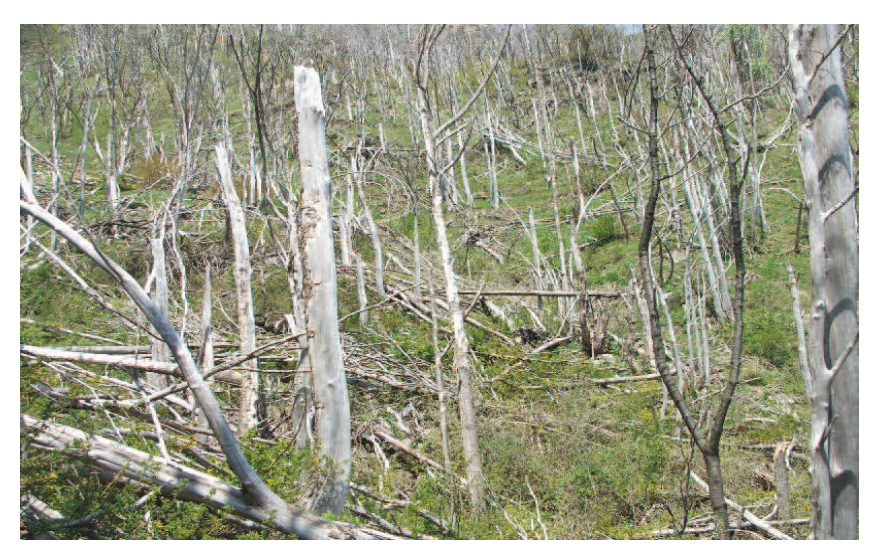

High fire severity 


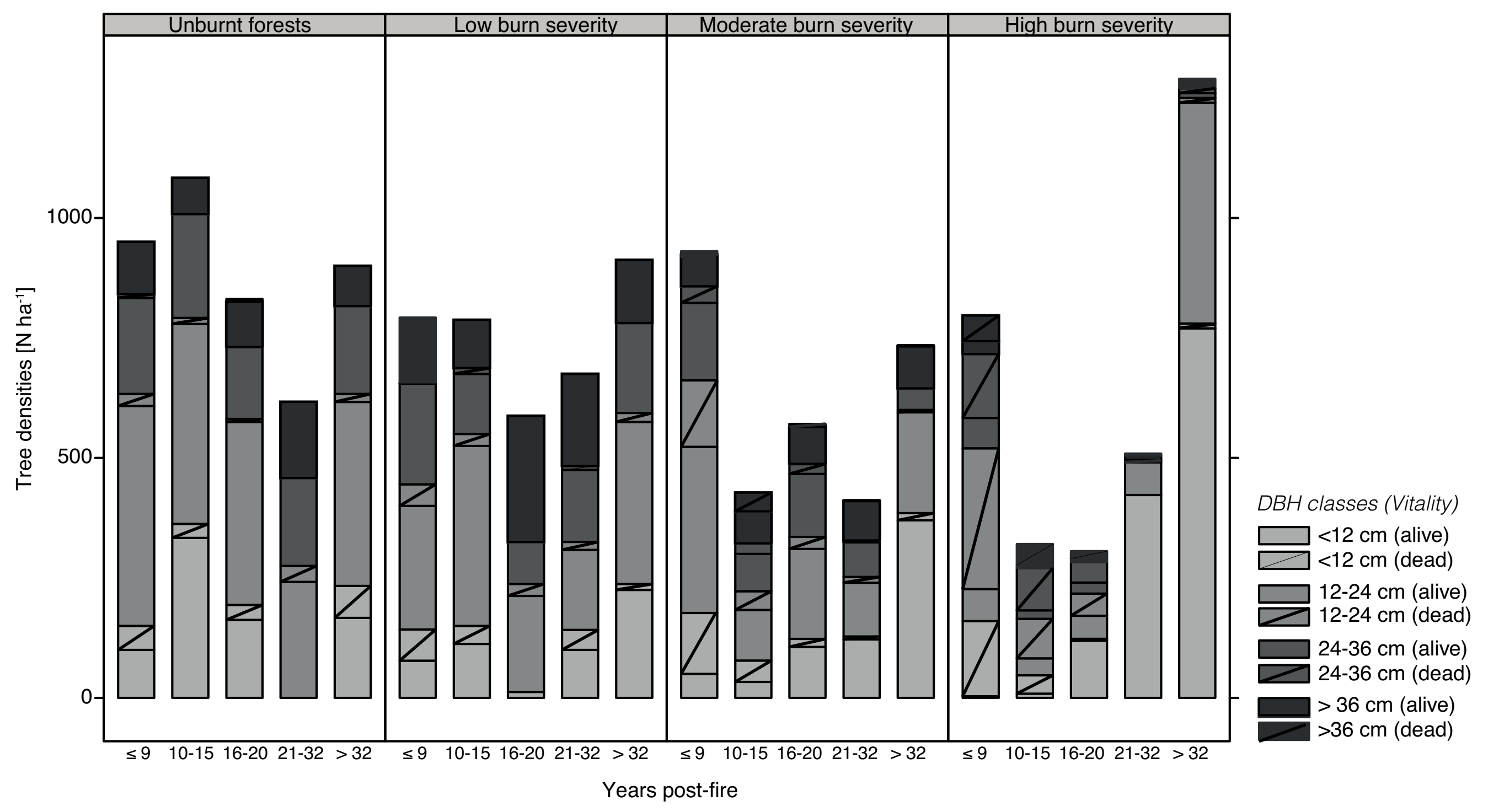




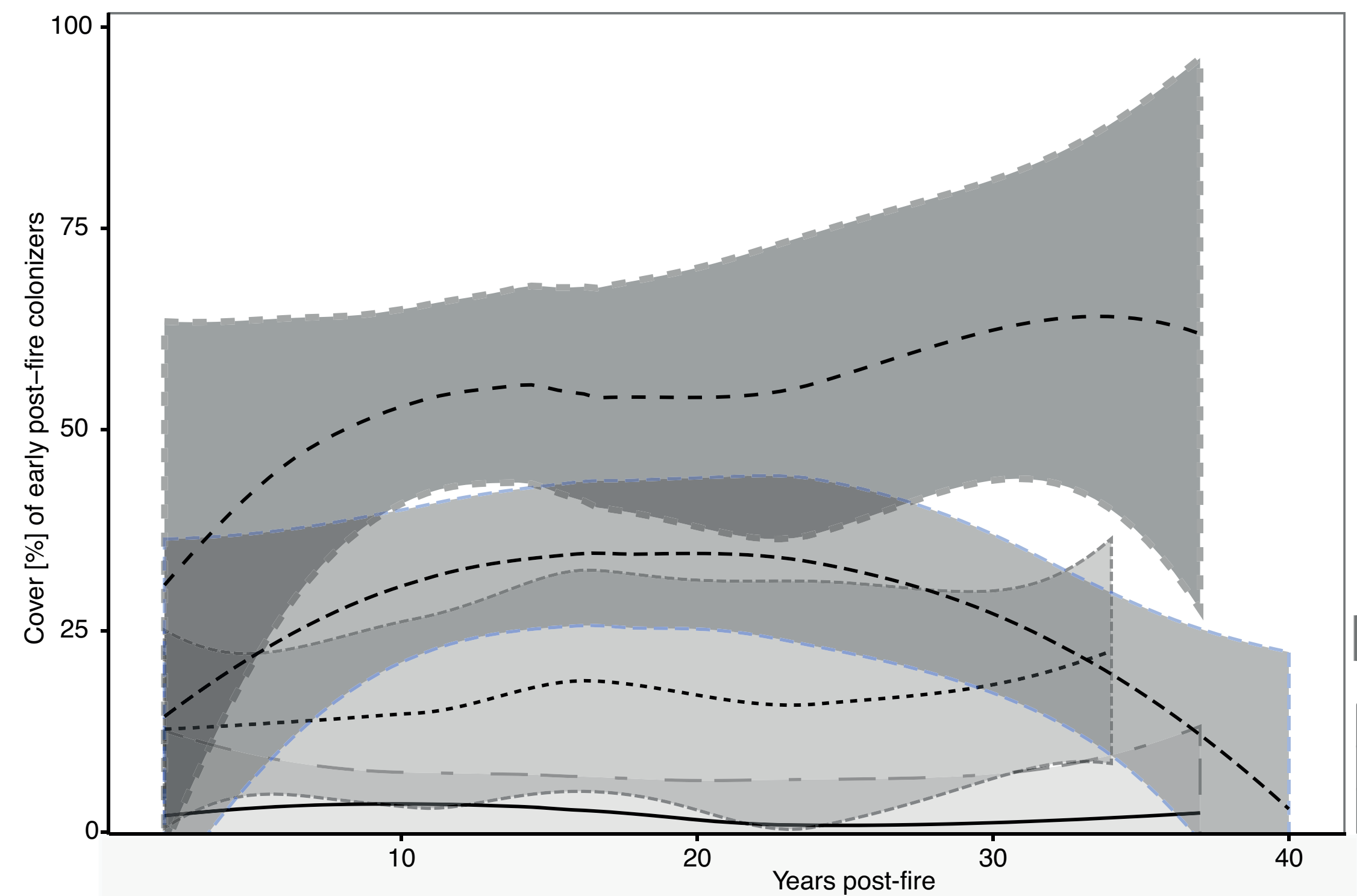

—unburnt forests

Burn severity classes

-.. low

- moderate

- - high

Years post-fire 


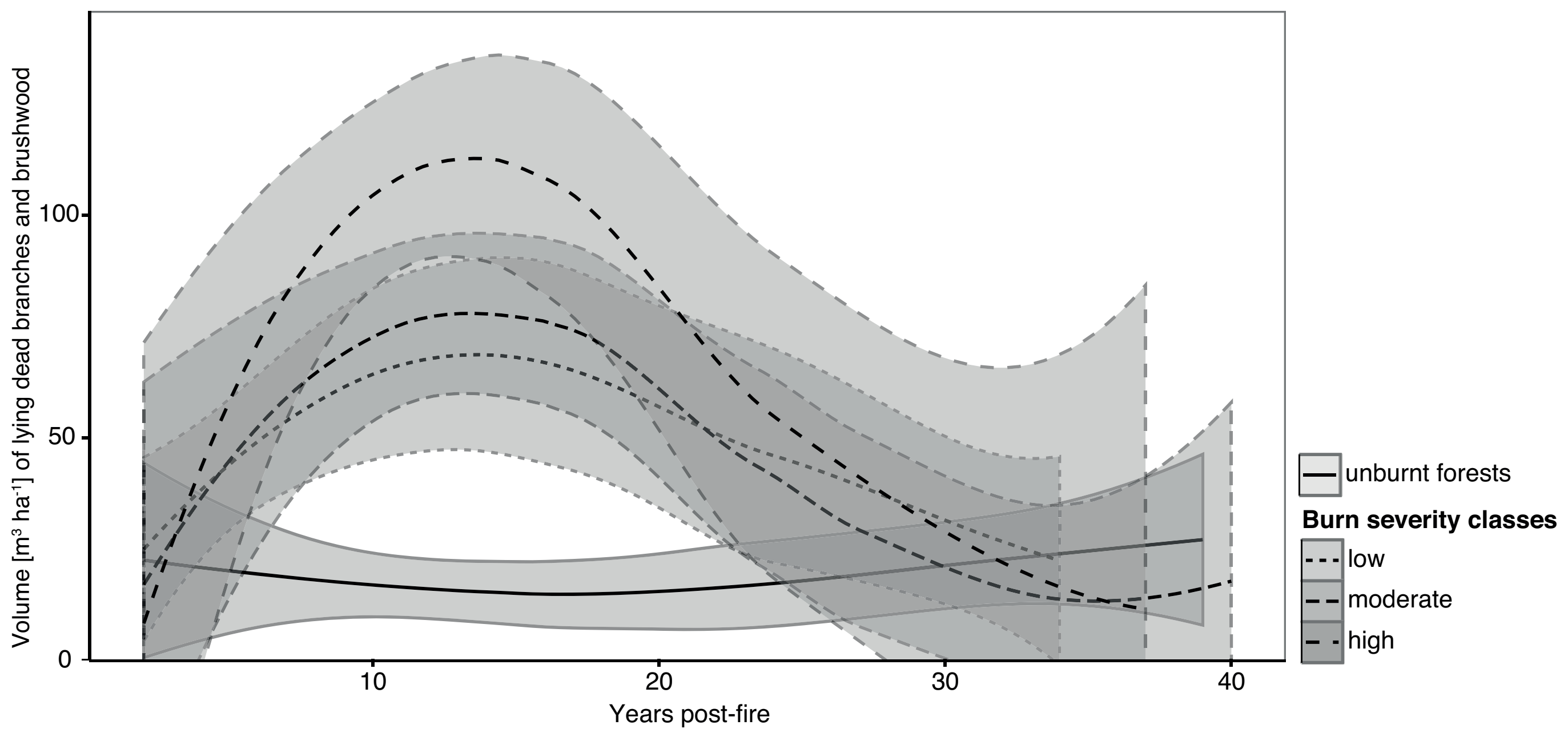


Scenario: Stone $=0.05 \mathrm{~m}^{3} ;$ Slope: $-27^{\circ} \cdots 30^{\circ}--35^{\circ}$

(a) Slope length $=75 \mathrm{~m}$

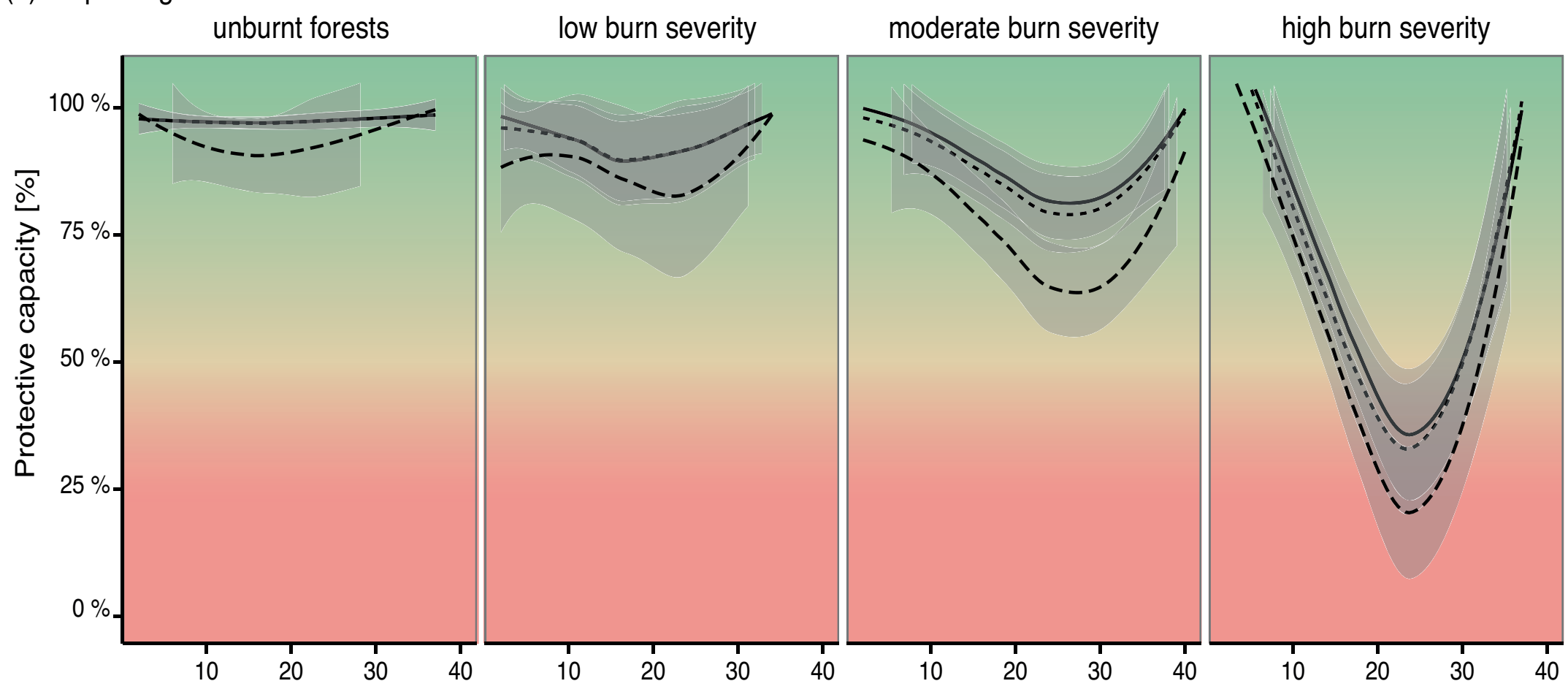

(b) Slope length $=150 \mathrm{~m}$

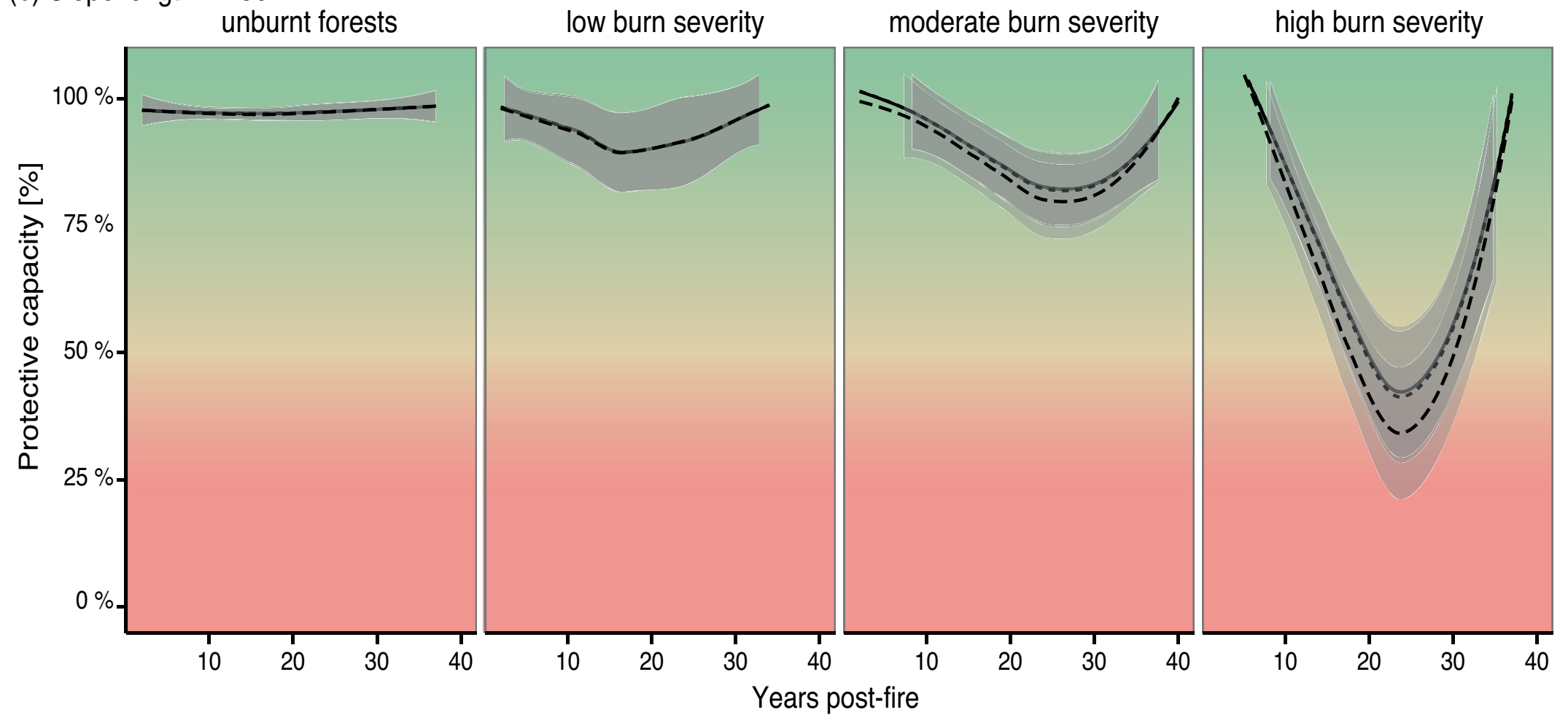


Figure Scenario: Stone $0.2 \mathrm{~m}^{3}$; Slope $-27^{\circ}-.-30^{\circ}--35^{\circ}$

(a) Slope length $=75 \mathrm{~m}$
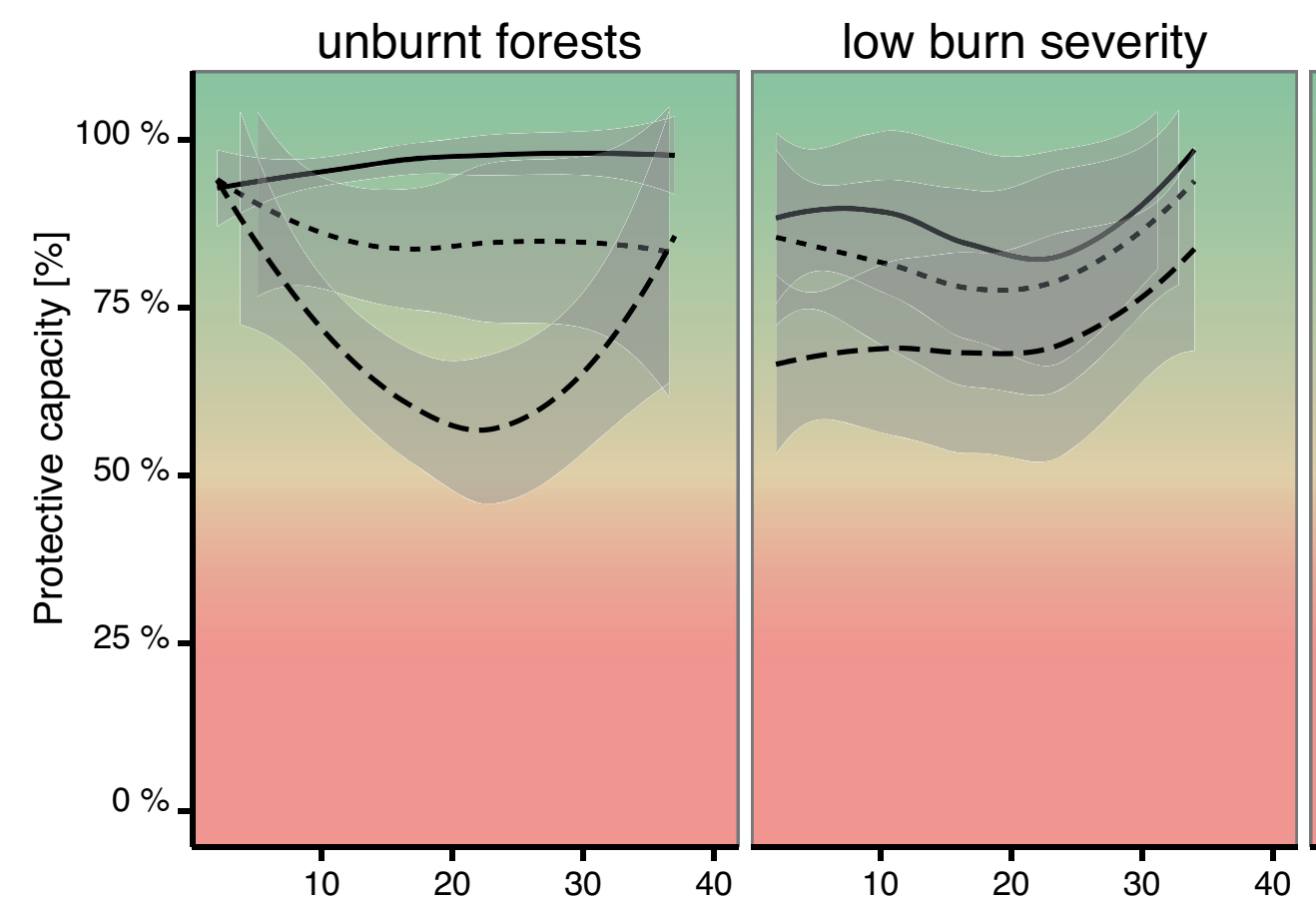

moderate burn severity high burn severity

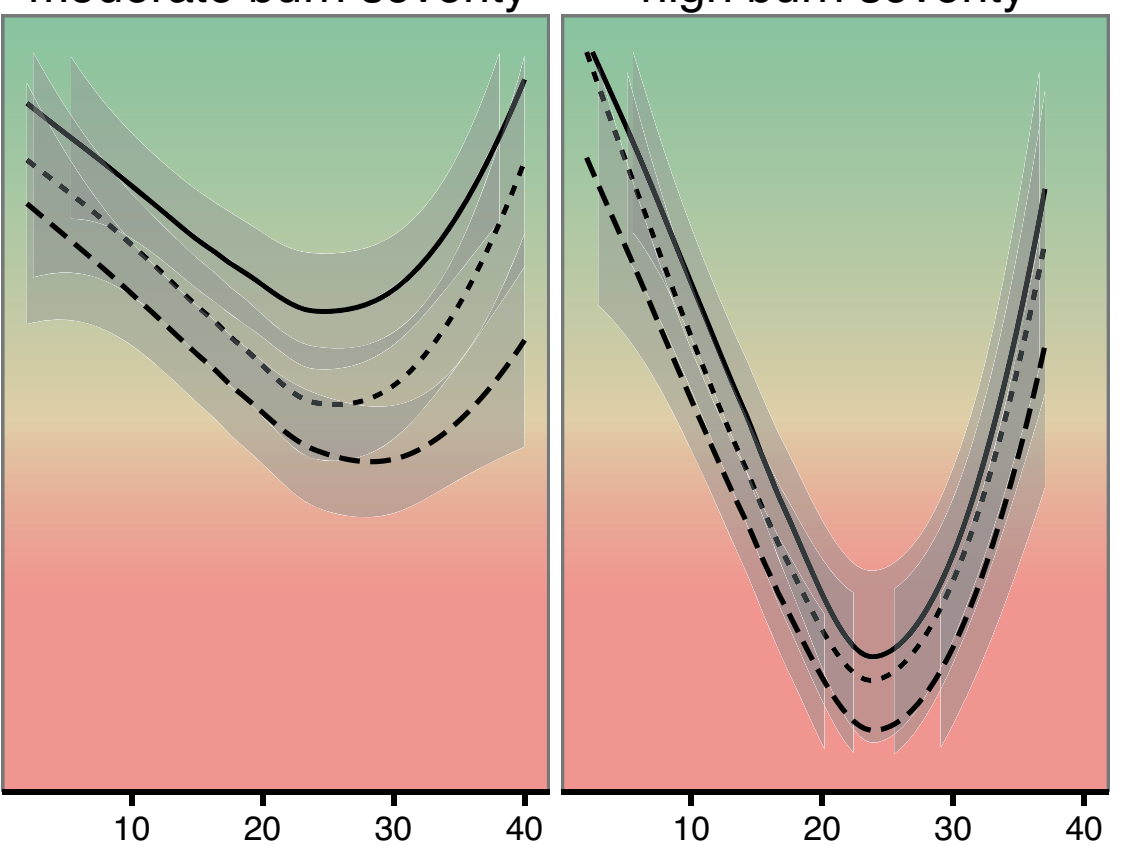

(b) Slope length $=150 \mathrm{~m}$
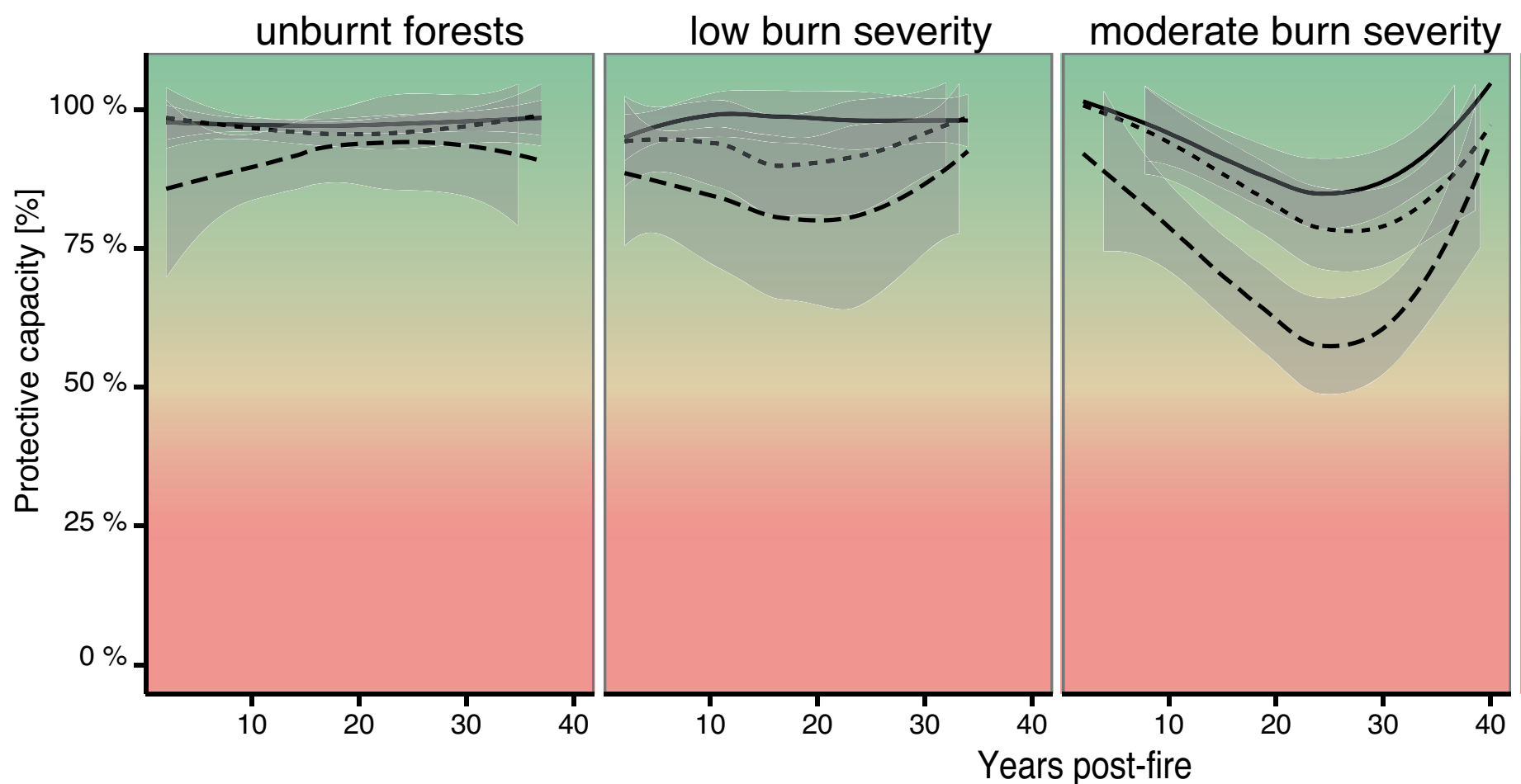

high burn severity

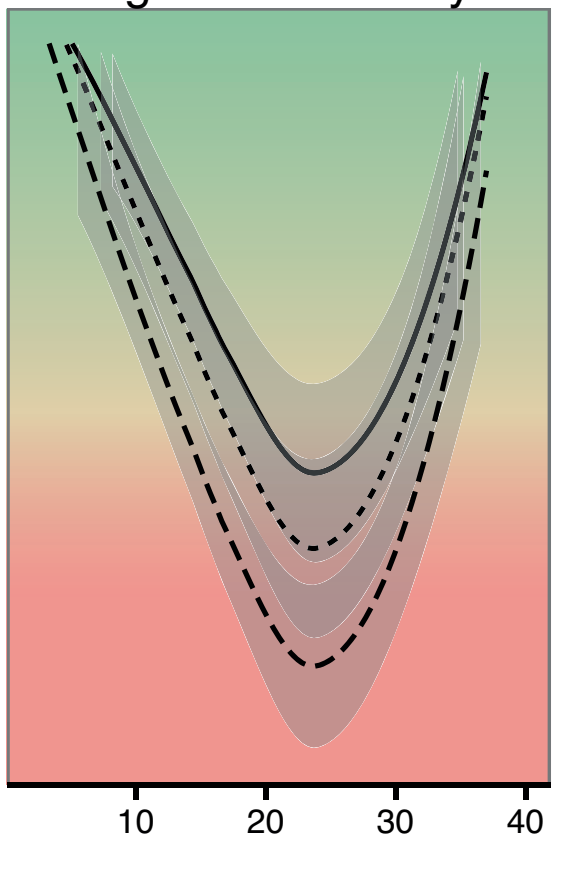


Scenario: Stone $1 \mathrm{~m}^{3}$; Slope: $-27^{\circ} \cdots 30^{\circ}--35^{\circ}$

(a) Slope length $=75 \mathrm{~m}$

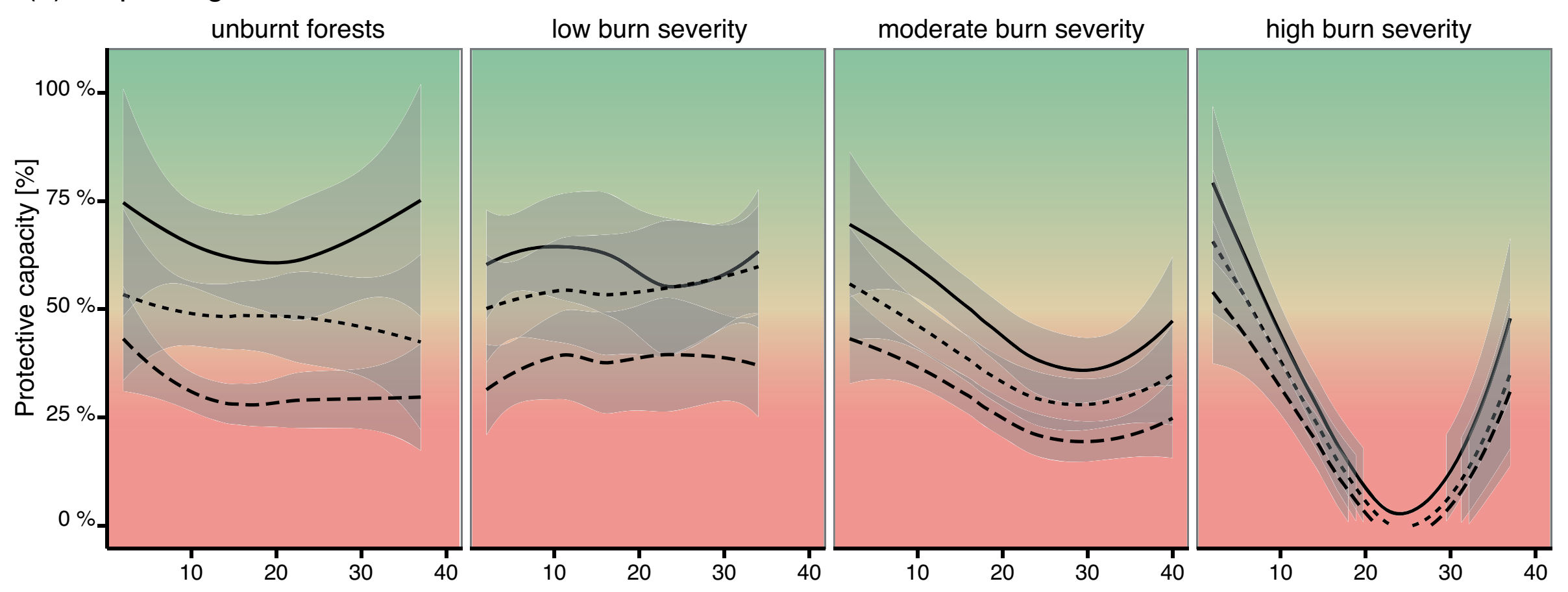

(b) Slope length $=150 \mathrm{~m}$

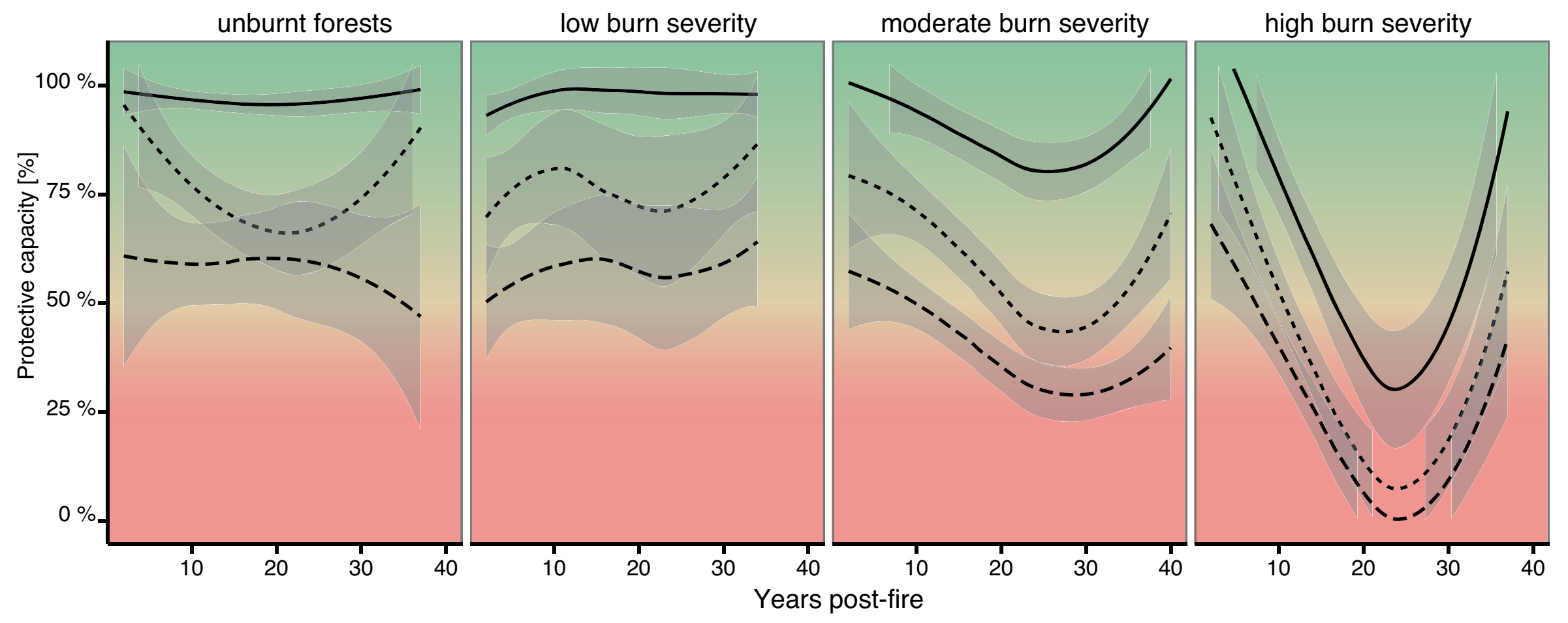

